National

Academy

of

Sciences

National Research Council

NUCLEAR SCIENCE SERIES

The Radiochemistry of Molybdenum 


\section{COMMITTEE ON CHEMICAL SCIENCES}

James L. Kinsey, Cochairman, Massachusetts Institute of Technology

Alan Schriesheim, Cochairman, Exxon Research and Engineering Company

Andreas Acrivos, Stanford University

Allen J. Bard, University of Texas, Austin

Fred Basolo, Northwestern University

Steven J. Benkovic, Pennsylvania State University

Bruce J. Berne, Columbia University

R. Stephen Berry, University of Chicago

Alfred E. Brown, Celanese Corporation

Ernest L. Eliel, University of North Carolina

Roald Hoffmann, Cornell University

Rudolph Pariser, E. I. Du Pont de Nemours \& Co., Inc.

Norman Sutin, Brookhaven National Laboratory

Barry M. Trost, University of Wisconsin

Edel Wasserman, E. I. du Pont de Nemours \& Co., Inc.

\section{SUBCOMMITTEE ON NUCLEAR AND RADIOCHEMISTRY}

Gregory R. Choppin, Chairman, Florida State University

Eugene T. Chulick, Babcock \& Wilcox Co.

Christopher Gatrousis, Lawrence Livermore National Laboratory

Peter E. Haustein, Brookhaven National Laboratory

Darleane C. Hoffman, Los Alamos National Laboratory

Paul J. Karol, Carnegie-Mellon University

Michael J. Welch, Washington University School of Medicine

Raymond G. Wymer, Oak Ridge National Laboratory

William H. Zoller, University of Maryland

\section{LIAISON MEMBERS}

Fred Basolo, Northwestern University

Theodore L. Cairns, Greenville, Delaware

Gerhart Friedlander, Brookhaven National Laboratory

(Membership as of January 1982) 


\section{DISCLAIMER}

This report was prepared as an account of work sponsored by an agency of the United States Government. Neither the United States Government nor any agency Thereof, nor any of their employees, makes any warranty, express or implied, or assumes any legal liability or responsibility for the accuracy, completeness, or usefulness of any information, apparatus, product, or process disclosed, or represents that its use would not infringe privately owned rights. Reference herein to any specific commercial product, process, or service by trade name, trademark, manufacturer, or otherwise does not necessarily constitute or imply its endorsement, recommendation, or favoring by the United States Government or any agency thereof. The views and opinions of authors expressed herein do not necessarily state or reflect those of the United States Government or any agency thereof. 


\section{DISCLAIMER}

Portions of this document may be illegible in electronic image products. Images are produced from the best available original document. 


\title{
The Radiochemistry of Molybdenum
}

\author{
By E. M. SCADDEN \\ and \\ N. E. BALLOU \\ U. S. Naval Radiological Defense Laboratory \\ San Francisco, California \\ January 1960
}

受

Reprinted by the Technical Information Center

U. S. Department of Energy

Subcommittee on Radiochemistry

National Academy of Sciences - National Research Council 
Price \$9.00. Available from:

National Technical Information Service U. S. Department of Commerce

Springfield, Virginia 22161

\section{Printed in the United States of America}

USDOE Technical Information Center, Oak Ridge, Tennessee

1960; latest printing June 1982 


\section{FOREWORD}

The Subcomittee on Radiochemistry is one of number of subcomittees working under the Committee on Nuclear science within the National Academy of Sciences-National Research Council. Its members represent government, industrial, and university laboratories in the areas of nuclear chemistry and analytical chemistry.

The Subcommittee has concerned itself with those areas of nuclear science which involve the chemist, such as the collection and distribution of radiochemical procedures, the establishment of specifications for radiochemically pure reagents, the problems of stockpiling uncontaminated materials, the availability of cyciotron time for service irradiations, the place of radiochemistry in the uadergraduate college program, etc.

This series of monographs has grown out of the need for up-to-date compilations of radiochemical information and procedures. The Subcomittee has endeavored to present a series which will be of naximum use to the working scientist and which contains the latest available information. Fach monograph collects in one volume the pertinent information required for radiochemical work with an individual element or a group of closely related elements.

An expert in the radiochemistry of the particular element has written the monograph, following a standard format developed by the Subcommittee. The Atomic Energy Commission has sponsored the printing of the series.

The Subcommittee is confident these publications will be useful not only to the radiochemist but also to the research worker in other fields such as physics, biochemistry or medicine who wishes to use radiochemical techniques to solve a specific problem.

W. Wayne Meinke, Chairman Subcommittee on Radiochemistry 


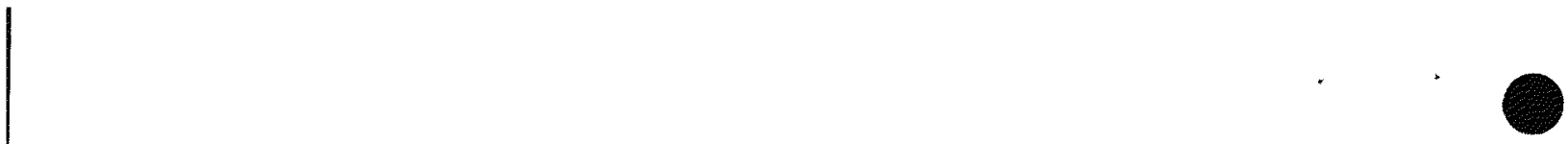

) 


\section{CONTENTS}

Page

I. General Reviews of the Inorganic and Analytical Chemistry of Molybdenum

II. Table of Isotopes of Molybdenum

III. Review of Those Features of Molybdenum Chemistry of Chief Interest to Radiochemists

1. Metallic molybdenum and molybdenum trioxide

2. Soluble compounds of molybdenum

3. Insoluble compounds of molybdenum

4. Complex ions of molybdenum

5. Chelate compounds of molybdenum

6. Solvent Extraction of molybdenum

7. Chromatographic behavior of molybdenum

8. Electrochemical behavior of molybdenum

IV. Dissolution of Samples for Radioactive Molybdenur Determinations

V. Counting Techniques for Radioactive Molybdenum

VI. Collection of Detailed Radiochemical Procedures for Molybdenum 


\section{INTRODUCTION}

This volume which deals with the radiochemistry of molybdenum is one of a series of monographs on radiochemistry of the elements. There is included a review of the nuclear and chemical features of partucular interest to the radiochemist, a discussion of problems of dissolution of a sample and counting techniques, and finally, a collection of radiochemical procedures for the elements as found in the literature.

The series of monographs will cover all elements for which radiochemical procedures are pertinent. plans inciude revision of the monograph periodically as new techniques and procedures warrant. The reader is therefore encouraged to call to the attention of the author any published or unpublished material on the radiochemistry of molybdenum which might be included in a revised version of the monograph. 
I. GENERAI REVIEWS OF THE INORGANIC AND ANAIYTICAI CHEMTSTRY OF MOLYBDENUM

"A Comprehensive Treatise on Inorganic and Theoretical Chemistry",

J. W. Mellor, Vol. XI, Chapter LXI, Longmans, Green and Co., New York (1931)

"Analytical Chemistry of the Manhattan Project", C. J. Rodden and J. Co Warf, pp. 450-455, Morraw-Hill Book Co., New York (1950)

"Applied Inorganic Analysis", Hillebrand, Lundell, Bright and Hoffman, 2nd ed., "Molybdenum", pp. 302-316, John Wiley and Sons, Inc., New Iork (1953)

"Pritz Ephraim Inorganic Chemistry", R. C. L. Thorne and $\mathrm{F}_{*}$ R. Roberts, Chapter 18, 6th ed., rev., Nordeman Publishing Co., Inc., New York (1954)

"Gmelin"s Handbuch der Anorganischen Chemie", Systam No. 53, 8th ed., Verlag Chemie, G.M.B.H. Berlin (1935)

"MoIybdenum Compounds", D. H. Killeffer and A, Linz, Interscience Publishers, New York (1952)

"Outlines of Methods of Chemical Analysis", G.E.F. Lundell and J.I. Hoffman, John Wiley and Sons, Inc., New York (1938)

"Qualitative Analysis for the Rare Elements", A.A. Noyes and W.G. Bray, The Macmillan Co., New York (1948)

"Reference Book of Inorganic Chemistry", W.M. Iatimer and J.H. Hildebrand, 3rd ed., The Macmilizan Co., New York (1951)

"Scott's Standard Methods of Chemical Analysis", N.H. Furman, Editor", 5th ed., Vol. I, "Molybdenum", pp. 585-613, D. Van Nostrand Co., Inc., New York (1939)

"Treatise on Inorganic Chemistry", H. Remy, Vol. II, Elsevier Publishing Co., New York (1956) 


\begin{tabular}{|c|c|c|c|}
\hline Isotope & 遇if ife & $\begin{array}{l}\text { Type of } \\
\text { Decay }\end{array}$ & Method of Properation \\
\hline $\mathrm{Mo}^{90}$ & $5.7 \mathrm{hr}$ & $\beta^{+}, \mathrm{EC}$ & $\mathrm{mb}^{93}(\mathrm{p},-)$ Mo90 \\
\hline Mo 91 m & $66 \mathrm{sec}$ & $\operatorname{IT}(57 \%), B^{+}, \operatorname{ICC}$ & $\mathrm{Mo}^{92}(\gamma, \mathrm{n}) \mathrm{Mo}^{91 \mathrm{~m}}$ \\
\hline $\mathrm{Mo}^{91}$ & $15.5 \min$ & $\beta^{+}$, No $\gamma$ & $\begin{array}{l}\operatorname{Mo}^{92}(\gamma, n) M^{91} \\
\text { Mo92 }(n, 2 n) M_{0}^{91}\end{array}$ \\
\hline Mo93m & $6.95 \mathrm{hr}$ & TT & $\begin{array}{l}\mathrm{mb}^{93}(\mathrm{~d}, 2 \mathrm{2n}) \mathrm{Mo}^{93 m} \\
\mathrm{mb}^{93}(\mathrm{p}, \mathrm{n}) \mathrm{Mo}^{93 \mathrm{~m}}\end{array}$ \\
\hline $\mathrm{Mo}^{93}$ & $>2 \mathrm{yrs}$ & $\mathrm{EC}$ & same as Mo93m \\
\hline $\mathrm{Mo}^{99}$ & $66.0 \mathrm{hr}$ & $\beta^{-}, \gamma$ & $\begin{array}{l}\text { Pisgion } \\
\text { Mo } 98(n, y) M^{99} \\
M_{0} 100(y, n) M_{0}^{99}\end{array}$ \\
\hline $\mathrm{Mo}^{101}$ & $14.6 \mathrm{~min}$ & $\beta^{-}, \gamma$ & fisston \\
\hline $\mathrm{Mo}^{102}$ & $11.5 \mathrm{~min}$ & $\beta^{-}$ & fisaton \\
\hline $\mathrm{Mo}^{105}$ & $<2$ min & $\beta^{-}$ & Lisa1on \\
\hline
\end{tabular}

See "Table of Isotopes" by D. Strominger, J. Hollander and G. Saaborg, Reviews of Modern Physics 30, No. 2, Part II, Apr11 1958 for more informtion concerning decay schemes, daughter products, etc. and for references to the original Iiterature.

III. REVIEWS OF THOSE FWATURES OF MOLYBDENU CHMMISTRY OF CHIER INTEREST TO RADIOCHRMISTS

1. Metallic Molybdenum and Molybdenum Trloxide

Molybdenum is a hard metal; grey in powder form and silvery in appearance in compact form. It has a density of 10.2 and ita melting point is about $2620^{\circ} \mathrm{C}$. The potential $\left(\mathrm{E}_{\mathrm{B}}^{\circ}\right.$ ) for the Mo-Mo(VI) couple is +1.05 volts. ${ }^{1}$ Methods of preparation of the metal include reduction of molybdenum triaxide with hydrogen or carbon or reduction of ammonium molybate with hydrogen. Surface oxidation of the metal proceeds slowly at room temperature.

The metal is soluble in dilute nitric acid, centrated sulfuric acid. Concentrated nitric acid rendere the metal passive. 
It is insoluble in concentrated hydrochloric acid, hydrofluoric acld (though soluble in a mixture of nitric and hydrofluoric or sulfuric acids), cold concentrated sulfuric acid, dilute sulfuric acid, or for all practical purposes aqueous potassium or sodiun hydroxide. Fusion with potassium nitrite, -nitrate,-chlorate, sodium peroxide, or sodium carbonate plus potassium nitrate, oxidizes the metal to a soluble molybdate.

Molybdenum trioxide, $\mathrm{MOO}_{3}$, is a white powder, slightly soluble in water, readily soluble in caustic alkalis, ammonium hydroxide or in alkaline solutions generally. Ignited molybdenum oxide ie soluble in hydrofluoric or concentrated sulfuric acid. Molybdic oxlde melta at $791^{\circ} \mathrm{C}$. According to T. Dupuis and C. Duval, ${ }^{2}$ the osside does not aublime below $780^{\circ} \mathrm{C}$. These authors report reagents, weighing forms and temperature limita for the ignition of various compounds of molybdenum. S. C. Llang and K. N. Chang 3 recomend ignition of molybdic oxide at $500-550^{\circ} \mathrm{C}$ for analytical purposes.

Methods of preparation of molybdenum trioxide include oxidation of the metal or molybdenite $\left(\mathrm{MaS}_{2}\right)$ by ignition in air or by decomposition of molybdates with acida such as nitric or hydrochloric.

\section{Soluble Compounds of Molybdenum}

Molybdenum has six oxidation states: $0,+2,+3,+4,+5$, and +6 . The +5 oxidation state is the one most commonly found in aqueous solution. Molybdenum is generally considered to exist in solution as an oxygenated anion in the +6 state. It is easily reduced by the ususil reducing agents such as zinc, stannous chloride, sulfur dioxlde, hydrazine, etc. Under controlled conditions, f.e., in neutral or slightly acid solution, mild reduction of molybdenum(VI) will produce molybdenum blue, otherwise molybdenum(III) is the usual end product. It is not yet known what the exact nature of the blue intermediate reduction product 1s, whether it is a mixture of the +6 and +5 or the +6 and +4 oxidation states.

Molybdenum(III) is very sensitive to oxidation and must be protected from air (oxygen) and other oxidizing substances. 
When molybdenum(VI) is reduced with reury, molybdenum blue is not produced but the product of the reduction is molybdenum(y) which is also susceptible to air oxidation. The +5 state can bo partially tabilized by the prosence of a complexing lon such a thiocyanate.

Water soluble compounds of nolybdenum(VI) include the amonium, sodium, potassium and magnesium salts of normal molybdates.

\section{Insoluble Compounds of Molybdenum}

Table I lists the ordinary incoluble compounds of molsbdenum. The nor mal molybdates are generally all readily soluble in acids.

Silver and lead molybdate, molybdenum cupferrate, 8-hydroxyquinolate and $\alpha$-benzoinoximate have all been used in the gravimetric determination of moly bdenum in radiochemistry.

The precipitating properties of these reagents for molybdenum, the fission products and other elements which be present in the solution will be briefly reviewed. Detailed discusaions concerming their use in analysis will be found in the references in part $I$.

Lead molybdate: The gravimetric determination of molybdenum as lead molybdate is a commonly ensployed procedure in radochemistxy. The molybdate is precipitated from hot, weakly acid solution by the addition of lead nitrate. The precipitate may be dried at $110^{\circ}$ or ignited to red heat. Lead molybdate is preferable to silver molybdate because conditions for precipitation (absence of chloride and sulfate ion) are not as critical.

Molybdenum cupferrate: Molybdenum is precipitated from a fairly trong acid solution by cupferron (nitrosophenylhydroxylsmine). However, cupforron is not a selective reagent for molybdenum as it will also precipitate of the fission products, e.g., $\mathrm{Zr}, \mathrm{Nb}, \mathrm{Pd}$, etc., $\mathrm{U}(\mathrm{IV})$ (but not $U(\mathrm{VI})$ ) and other elements. Therefore it is useful as a precipitant for the determination of the yield of molybdenum only in solutions where these elements are not present or are preferentially complexed. The cupferrate can be ignited and molybdenum determined as molybdenum trioxide. 
TABIE I. IRSOLDBLE COMPOUNDS OF MOLIBDEMUM

\section{INORGANIC}

\begin{tabular}{|c|c|c|c|}
\hline Reagent & Precipitate & $\begin{array}{l}\text { Solubility in } \\
\text { Water }\end{array}$ & $\begin{array}{c}\text { Solubility in Other } \\
\text { Resgents }\end{array}$ \\
\hline $\mathrm{Ag}^{+}$ & $\mathrm{Ag}_{2} \mathrm{MOO}_{4}$ & $.0044 \mathrm{gms} / 100 \mathrm{mls}\left(25^{\circ}\right)$ & s. $\mathrm{HNO}_{3} \mathrm{KCN}, \mathrm{NaOH}, \mathrm{NH}_{4} \mathrm{OH}$ solns. \\
\hline $\mathrm{Ba}^{+2}$ & $\mathrm{BaMOO}_{4}$ & $.0058 \mathrm{gms} / 100 \mathrm{mls}\left(23^{\circ}\right)$ & 81. sol. in acid \\
\hline $\mathrm{BI}^{+3}$ & $\mathrm{Bi}_{2}\left(\mathrm{MoO}_{4}\right)_{3}$ & $.02 \mathrm{gms} / 100 \mathrm{gms}$ & v. sol. in acida \\
\hline $\mathrm{Ca}^{+2}$ & $\mathrm{CaMOO}_{4}$ & insoluble & s. acids, 1. alcohol and ether \\
\hline $\mathrm{Ca}^{+2}$ & $\mathrm{CaMoO}_{4}$ & s1. soluble & s. acids, $\mathrm{NH}_{4} \mathrm{OH}, \mathrm{KCN}$ \\
\hline $\mathrm{Hg}_{2}^{+2}$ & $\mathrm{Hg}_{2} \mathrm{MOO}_{4}$ & insoluble & \\
\hline$I_{A}+3$ & $\mathrm{Ia}_{2}\left(\mathrm{MOO}_{4}\right)_{3}$ & s1. soluble & s. acids \\
\hline $\mathrm{Pb}^{+2}$ & $\mathrm{PbMOO}_{4}$ & insoluble & $\begin{array}{l}\text { d. conc. } \mathrm{H}_{2} \mathrm{SO}_{4}, \text { s. acids, } \mathrm{KOH}, \\
\text { i. alcohol }\end{array}$ \\
\hline $\mathrm{Sr}^{+2}$ & $\mathrm{SrMOO}_{4}$ & $.0104 \mathrm{gms} / 100 \mathrm{mla}\left(17^{\circ}\right)$ & a. acids \\
\hline $\mathrm{Th}^{+4}$ & $\mathrm{Th}\left(\mathrm{MoO}_{4}\right)_{2}$ & insoluble & s. acids \\
\hline$S=$ & $\mathrm{MOS}_{3}$ & insoluble & c. $\mathrm{NH}_{4} \mathrm{OH}$, alkaline sulfides \\
\hline
\end{tabular}

ORGANIC

\begin{tabular}{|c|c|c|}
\hline Reagent & Precipitated from & Soluble in \\
\hline cupferron* & $1-2 \mathrm{M} H \mathrm{HCl}$ or $\mathrm{H}_{2} \mathrm{SO}_{4}$ & $6 \mathrm{~N} \mathrm{HNO}_{3}^{\dagger}, 6 \mathrm{NH}_{4}$ OH \\
\hline 8-hydroxyquinoline & $\begin{array}{l}\text { buffered acid solution, } \\
\text { e.g., acetic acid-acetate }\end{array}$ & mineral acid \\
\hline$\alpha$-benzoinoxime & M acid solutions & fuming $\mathrm{HNO}_{3}, \mathrm{NH}_{4} \mathrm{OH}+\mathrm{H}_{2} \mathrm{O}_{2}$ \\
\hline
\end{tabular}

Molybdenum oxinate: 8-hydroxyquinoline (oxine) as a reagent for molybdenum has the same property as cupferron, 1.e., it precipitates a large number of elements from a slightly acid or alkaline solution. According to Pribil and Malat ${ }^{4}$, molybdenum can be separated from $\mathrm{Fe}(\mathrm{III}), \mathrm{Al}, \mathrm{Be}, \mathrm{Zn}, \mathrm{Ni}, \mathrm{Co}, \mathrm{Mn}, \mathrm{Pb}$, 
$\mathrm{Cd}, \mathrm{BI}, \mathrm{Cu}$ and $\mathrm{Hg}$ (II) by precipitation of molybdenum oxinate from an amonium acetate-acetic acid buffered solution containing the di-sodium salt of BDTA (ethylenediaminetetraacetic acid). Tungsten (VI), V(V) and U(VI) also precipitate. Titanium must be removed before precipitation. Milinek states that $V$ can be held in solution by reducing it to $V(I I)$ and then complexing it with EDTA at pH 1-2. Molybdenum oxinate my be dried at 40-270 and welghed as $\mathrm{MoO}_{2}\left[\mathrm{C}_{9} \mathrm{H}_{6} \text { ON }\right]_{2}{ }^{2}$

Molybdenum $\alpha$-benzoinoximate: Alpha-benzoinoxime is practically a specific reagent for molybdenum. ${ }^{6}$ Only $\mathrm{W}, \mathrm{Pd}, \mathrm{V}(\mathrm{V}), \mathrm{Nb}, \mathrm{Ta}$ and $\mathrm{Cr}(\mathrm{VI})$ interfere in the precipitation of molybdenum from I M acid solution by the addition of an alcoholic solution of the reegent. Chromium and vanadium can be reduced to lower valence states in which they do not precipitate. Niobium, $W, T a$ and $P d$ must be removed. In fission product chemistry, niobium is removed as the hydrated oxide with iron as carrier. Palladium radioactivity is so insignificant in comparison to the molybdenum activity in low energy fission that no special procedure is required to remove 1.

Molybdenum oximate my be Ignited and weighed as molybdic oxide.

Molybdenum sulfide: Molybdenum sulfide is generally not used in the gravimetric determination of molybdenum in radiochemistry, for there are far better methods available. It has been employed as a means of separating molybdenum from the fission products which do not form sulfides in acid solution. 7,8

Molybdenum sulfide is precipitated by passing $\mathrm{H}_{2} \mathrm{~S}$ through the acid solution containing molybdenum or by acidifying a thiomolybdate solution. Molybdenum sulfide should not be welghed as such because its composition is generally indefinite. ( $\mathrm{H}_{2} \mathrm{~S}$ reduces some of the molybdenum to lower oxidation states.) Also, according to Duval ${ }^{9}$, there is no plateau in the thermogravimetric curve until the sulfide has been converted to molybdic oxide. The sulfide should be ignited carefully and weighed as molybdic oxide.

Coprecipitation of molvbdenum: Several methods are mentioned here which, while not dealing specifically with tracer amounts of molybdenum, were used to 
separate, presumably quantitatively, microgram quantities of molybdenum, and therefore might be applicable to the carrying of tracer molybdenum.

Picket and Hankins ${ }^{10}$ made a study of the co-precipitation of molybdenum, cobalt and copper, in tracer and $\mu \mathrm{gm}$. amounts, as the 8-hydroxyquinolates with indium or aluminum as carriers. Precipitation was from an ammonium acetate buffered solution at pH 5.2. Aluminum or indium oxinate alone carried 85 per cent or more of the molybdenum present. In the presence of oxine plus tannic acid and thioanilide, aluminum or indium carried better than 95 per cent of the molybdenum.

Niobium, tellurium and molybdenum are specifically removed from a solution of the fission products which is more than $10 \mathrm{M}$ in nitric acid by comprecipitation on manganese dioxide. ${ }^{11}$ Park $^{12}$ reported the practically quantitative carrying of 0.1-2 mgs. molybdenum, antimony and bismuth on manganese dioxide from one liter of boiling solution by the addition of potassium bromide and potassium permanganate. The procedure was used for separating trace impurities from copper. Pohl ${ }^{13}$ employed the ammonium salt of pyrolidine-dithiocarbamate, with thallium(I) as carrier, for precipitating a large number of trace impurities, including molybdenum, away from aluminum.

Scharrer and झberhardt ${ }^{14}$ precipitated 100 mgs. of bismuth as the sulfide to carry molybdenum as a preliminary separation in the determination of trace amounts of molybdenum in soils, plants and animal products. Molybdenum may be collected on other acid-insoluble sulfides such as antimony or copper.

Ultramicro quantities of molybdenum(VI) are quantitatively co-crystallized from slightly acid aqueous solutions with $\alpha$-benzoinoxime. An acetone solution of the reagent is added to the aqueous solution containing molybdenum at such concentration that the solution remains homogeneous. The solution is boiled to drive off the acetone whereupon, the oxime, due to its low solubility in water, crystallizes out carrying molybdenum with it. ${ }^{15}$

Molybdenum be separated from these atrices by dissolution or destruction of the precipitate, by solvent extraction, ion exchange techniques, precipitation of the carrier or a combination of these methods. 


\section{Complex Ions of Molybdenum}

Molybdenum chemistry is very complez and, as yet, not thoroughly understood or investigated. The posession of six oxidation atates (including the O state) does not simplify matters. Apparently a small change in the conditions, i.e., temperature, pH, concentrations, etc., of a particular system under investigation can sometimes markediy affect this system. This has led to a good deal of confusion and contradiction in the literature concerning molybdenum species, oxidation states involved and equilibria.

It is generally belleved that the principal molybdenum species existing in alkaline solution is the simple molybdate ion $\mathrm{MOO}_{4}=$. On acidifying ach a solution, i.e., lowering the pH past 7 , molgbdate lons condense to form polymolybdate ions. Iindqrist, ${ }^{16}$ on the besis of spectrophotometric studies has proposed the following sequence:

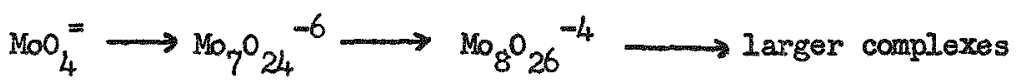

Molybdenum has a strong capacity for forming complex anions. Besides the isopolymolybdates, molybdenum forms (a) heteropoly acids, complexes of molybdic acid with phosphoric, silicic, telluric acids, etc., (b) peroxymolybdates, compounds or complexes of molybdates with hydrogen peroxide, (c) complexes in the (VI) and lower oxidation states with halides, cyanide, thiocyanate, etc., and (d) complexes or compounds with many organic substances, such as oxalic acid, citric acid, thioglycollic acid, phengl hydrazine, catechol, EDTA, 1, 10-phenanthroline, etc.

While many complexes or compounds, both organic and inorganic, are known, there is very little definite quantitative information available concerning their strengths or even their formulae.

Nelidow and Diamond ${ }^{17}$ studied the behavior of molybdenum in various solvent extraction systems. They proposed the formula $\mathrm{MOO}_{2} \mathrm{X}_{2}\left(\mathrm{H}_{2} \mathrm{O}\right)_{y}$ (Ether), where $X$ represents a halide ion, for the species extracting into diethyl or diisopropyl ether from 3-9 $\mathrm{M} \mathrm{HCI}$ or $6 \mathrm{M} \mathrm{HBr}$, and also discussed at length the possible factors involved in the mechanism of this solvent extraction system. Diamond, ${ }^{18}$ 
in a series of papers, has extended this study to the development of a general expression for the distribution coefficient of a metal halide between an aqueous hydrohalic acid phase and an organic solvent and has tested the validity of this expression for the extraction of molybdenum(VI) and indium(III). Some information was obtained concerning the aqueous molybdenum(VI) species; polymeric forms can exist at hydrohalic acid concentrations below $6 \mathrm{M}$ (and $<0.1 \mathrm{M}$ molybdenum); the main species are apparently the anions of acids stronger than $\mathrm{HCl}$.

Perrin ${ }^{19}$ investigated the nature of the molybdenum thiocyanate complex. Through spectrophotometric studies in $60 \%$ acetone-water solutions, he concluded that in IM hydrochloric acid, molybdenum(V) form thiocyenate complexes in which the ratio Mo:CNS 1 is $1: 3,1: 2$ and $1: 1$ for high, moderate and low concentrations of thiocyanate respectively. The 1:3 complex is amber, fairly stable, uncharged and probably $\mathrm{MOO}(\mathrm{CNS})_{3}$; this is the colored complex used in chemical analysis. The $1: 2$ complex is yellow and unstable. The $1: 1$ complex is colorless. The logs of the association conatants for the complexes in $60 \%$ acetone-water at $20-3^{\circ}$ and ionic atrength $1.07-1.10$, are $1.85,3.01$ and 3.2 for the $1: 3,1: 2$ and $1: 1$ complexes, respectively.

\section{Chelate Compounds of Molybdenum}

Molybdenum forms many chelate complexes or compounds. Some hove been used in nolybdenum radiochemistry, but their use has not been extensive.

Many molybdenum chelate complexes or compounds have been employed in analytical chemistry for the separation and/or determination of molybdenum in a wide variety of moterials and some of these chelates should be useful in the radiochemistry of molybdenum.

A brief discussion of a few molybdenum chelate complexes will show their broad application.

Precipitation with cupferron, 8-hydroxyquinoline and $\alpha$-benzoinoxime has already been mentioned (III, Part 3).

Acetylacetone is a 1,3-diketone which possesses the fairly unique characteristic of being both chelating agent and solvent and certain extractions 
may be carried out from high acid concentrations with it: Molybdenum, as $\mathrm{MOO}_{2}\left(\mathrm{C}_{5} \mathrm{H}_{7} \mathrm{O}_{2}\right)_{2}$, can be quantitatively extracted from $6 \mathrm{~N}$ sulfuric acid by a $1: 1$ mixture of acetylacetone and chloroform. 20

Molybdenum(VI), tungsten(VI) and rhenium(VII) in acid solution react with toluene-3,4-dithiol to form chelate compounds that are soluble in butyl or amyl acetate and carbon tetrachloride. 21,22 Gilbert ${ }^{23}$ found that there are three dithiol molecules to each molybdenum atom in the complex and also, that when molybdenum $(V)$ is treated with dithiol, the (V) complex disproportionates between the molybdenum(VI) complex and a molybdenum(IV) complex; the ratio of the (VI)/(IV) complexes depends on the acidity. Molybdenum(III) does not react. Molybdenum may be separated from tungsten by inhibiting the formation of the tungsten complex through control of the acid concentration or the addition of citric acid. $24-26$ Many procedures have been devised for the colorimetric determination of molybdenum with dithiol in steel $24,25,27$, drugs $^{26}$, plants $^{28,33}$, soils and rocks ${ }^{29-31}$, uranium ${ }^{32}$ and animal tissues 33 .

Ethylenediaminetetraacetic acid (EDTA) forms chelate complexes in acid solution with molybdemum(VI) and (V) in which there are two atoms of molybdenum to each molecule of EDTA. The EDTA complex holds molybdenum in the $(V)$ oxidation state in solution at $\mathrm{pH}<7$. The formulas for the (VI) and (V) complexes are $\mathrm{Na}_{4} \mathrm{Mo}_{2} \mathrm{O}_{22} \mathrm{H}_{28} \mathrm{C}_{10} \mathrm{~N}_{2}$ and $\mathrm{Na}_{2} \mathrm{Mo}_{2} \mathrm{O}_{13} \mathrm{H}_{4} \mathrm{C}_{10} \mathrm{~N}_{2}$ respectively. ${ }^{34}$ Molybdenum is held in solution by the di-sodium salt of EDTA while uranium(IV) is precipitated by cupferron at $\mathrm{pH}$ 4-6.35 However, EDTA does not affect the extraction of molybderam(VI) by 8-hydroxyquinoline into chloroform at $\mathrm{pH} 1.6-5.6 .36$ Also, as pointed out in Section III,3, precipitation of molybdenum oxinate from an ammonium acetate-acetic acid buffered solution containing the di-sodium salt of EDTA serves to separate Mo from a large number of other elements. 4

The compounds of molybdenum with cupferron ${ }^{37,38}$ (separation from rhenium) 39 and a-benzoinoxime 40 are soluble in chloroform. The extraction of molybdenum with a-benzoinoxime is the first step in a rapid spectrophotometric determination of the element in thorium oxide, uranyl sulfate and steel. 41 
Molybdenum may be separated from most metals in the presence of sodium fluoride or EDTA in 0.1-0.5 N hydrochloric acid by extraction with Morin into 1-butanol. 42

Molybdenum forms complexes with sodium diethyldithiocarbamate 43 (soluble in chloroform), xanthate ${ }^{44}$ (separation from rhenium ${ }^{45}$ and di-sodium-1, 2-dihydroxy-3,5-benzenedisulfonate (Tiron). 46 The Tiron complex is the basis of a very sensitive col rimetric (aqueous) procedure for molybdenum.

\section{Solvent Extraction}

The extraction of molybdenum from an aqueous solution into an organic solvent has been studied by many investigators for many different systems. A few of these have been briefly mentioned in Part 5: Chelate Compounds of Molybdenum.

Relatively little information is avalable in the literature concerning the extraction of radionctive molybdenum. However, there are numerous references for the detemination of microgram quantities of molybdenum in aoils, plants, steels, alloys, "pure" motals, etc. Which employ solvent oxtraction as a moans of determining the lement colorimetrically or spectrographically. Again, reference to these methods may prove helppul to the radiochemiat. "Colorimetric Methods of Analysis" by Snell and Sne $11^{47}$ and "Colorimetric Determination of Traces of Metals" by Sandel148 provide excellent coverage of this subject.

Two elassical methods wich heve been employed in the separation of fission product molybdenum are the extraction of the thiocyanate or chloride complexes of molybdenum into diethyl ether.

Thiocyanate: Molybdenum in dilute acid in the presence of a reducing agent, such as stannous chloride, forms a red-colored complex with thiocyanate. This reaction has been used for many years as a means of determining molybdenum colorimetrically. Hiakey and Meloche, ${ }^{49}$ in a study of the complex, stated that it was formed with molybdenum( $\nabla$ ) and that the ratio of thiocyanste to molybdenum was $3: 1$. R. Bock ${ }^{50}$ has ade a detalled inveatigation of the 
extraction of rarious metal thiocyanates at 0.1 concentrations into othyl other from 0.5 hydrochloric acid solutions which wer 1 to $7 \mathrm{M}$ in amonium thiocyanate. By varying the amonium thiocyanate concentration, volume otc., molybdenum can be separated from a number of fission products, uranium(VI) and other elements.

The molybdenum( $\nabla)$ complex is soluble in such solvents as anyl alcohol, butyl acetate, iso-propyl ether, ethyl acetate and cyclohezanol. Goto and Ireda 51 studied the extraction of molybdenum thiocyanate by various organic solvents for spectrophotometric purposes; ethyl acet to or iso-butyl alcohol and Its rixture with chloroform or carbon tetrechloride were suitable solvents.

Wilkinson and Grumitt ${ }^{8}$ incorporated the extraction of molybdenum( $\left.V\right)$ thiocyanate as a atep in a procedure for separating molybdenum from uranium and other fission products. Molybdenum sulfide was precipitated, dissolved in aqua regla and the molybdenum extracted from 4 hydrochloric acid solution into ethyl ether as the thiocyanate complex ( $\mathrm{n}$ was the reducing agent). Molybdenum was back extracted with $8 \mathrm{M}$ hydrochloric acid, and, after evaporation of the aqueous extract and treatment of the residue with nitric acid, was precipitated twice as lead molybdate.

Molybdenum can be separated from rhenium, ransilum and chromium by using mercury as the reducing agent (rhenium is not reduced) and then extracting the molybdenum $(\nabla)$ thiocyanate complex with butyl acetate (the colored vanadium and chromium reduction products are not soluble in butyl acetate). 52 In the presence of sodium fluoride and HDTA, molybdenurn is separated from titanium and other metsis by extraction of the thiocyanate complex by 2 1:I mixture of carbon tetrachloride and amyl alcohol. 53

Ethyl Ether: Molybdenum will extract into ethyl ether from halogen acid solutions. Swift ${ }^{54}$ reported $80-90 \%$ extraction from $6 \mathrm{M} \mathrm{BC}$. Other investigators report $54,9.7$ and 6.5 per cent extraction from $6 \mathrm{M} \mathrm{HBr}{ }^{55}$, $3.5 \mathrm{MHF}^{56}$ and $6.9 \mathrm{MHI}^{57}$ solutions, respectively. 
Stout and Meagher 58 prepared "carrier-free" Mo 93,99 , which had been produced in an $(\alpha, n)$ reaction with zirconium, by ether extraction. The zirconium target was dissolved in $12 \mathrm{~N} \mathrm{H}_{2} \mathrm{SO}_{4}$, the solution evaporated to fumes, then diluted with water and the chloride and hydrogen ion concentrations adjusted to 6 M. Molybdenum was then extracted quantitatively with diethyl ether. Wiles and Coryell $7^{59}$ used ether extractions to separate molybdenum from fission product mixtures. Molybdenum was extracted from $6 \mathrm{M} \mathrm{HCI}$, back extracted from the ther phase with water, the aqueous phase was scavenged with a ferric hydroxide precipitate and molybdenum precipitated as the 8-hydroxyquinolate for mounting and counting. See Procedure $C$ in Section VI in this report.

A rapid separation of molybdenum and technetium from fission products and each other was effected by extracting molybdenum(VI) with ether from a $6 \mathrm{MHCl}$ solution of irradiated uranium, precipitating the molybdenum with 8-hydroxyquinolate and separating or milking the technetium from molybdem by precipitating nitron pertechnetate with rhenium as the carrier. 60

Comparison of Solvents: Nelidow and Diamond ${ }^{17}$ conducted an extensive investigation of the extraction behavior of molybdenum(VI), using $\mathrm{Mo}^{99}$ and $M_{0}^{93 m}$ tracers, from aqueous halogen acid solutions into various ketones, esters, ethers, an alcohol and some non-oxygenated solvents. The original paper should be consulted for detailed information. A very brief resume of some of the results of their investigation follows.

The non-oxygenated solvents, carbon tetrachloride, chloroform, etc. were extremely poor extractants for molybdenum(VI). Of the oxygenated solvents, the ketones, esters and the alcohol were all bettex extractants than the cor responding ether; the order boing: esters and alcohol > ketones > ether. The nature of the halogen acid affected the extraction of molybdenum. In general, extractions from hydrobromic acid solutions were better and Irom hydrofluoric acid solutions were worse than extractions from hydrochloric acid solutions. The effect of temperature was also noted: better extractions were obtained at $5^{\circ}$ than at $45^{\circ}$ with the exception of extractions by the alcohol (2-ethylhexanol) which seemed to be independent of the temperature in the range examined. 
Vurying the inftal concentration of wolybdenum in the aquous phese Irom $10^{-9} \mathrm{M}$ to $10^{-2}$ ald not afrect the diatribution coerficient for the tro solvents tested (hexone and $B, \beta^{3}$-diehlorodiothyl other).

Tablo II is representative list of the solvent with which distribution coefficients, D, $[($ Mo $)$ org./(Mo) aq.] greater than 10 were observed at room temperature.

Table II

\begin{tabular}{|c|c|c|}
\hline Solvent & Aqueous Pbase & $D$ \\
\hline$\underset{n}{\text { Methyl isobutyl ketono (hezono) }}$ & $\begin{array}{l}6 \mathrm{MCI} \\
7 \mathrm{MCI} \\
5 \mathrm{MBr}\end{array}$ & $\begin{array}{l}20 \\
29 \\
17\end{array}$ \\
\hline $\begin{array}{l}\text { Dilsopropyl ketone } \\
\text { Isoamy I acot te } \\
\text { B, } \beta^{\prime}-d \text { lchlorodlethyl other }\end{array}$ & $\begin{array}{l}7 \mathrm{HBr} \\
7 \mathrm{MCI} \\
9 \mathrm{HBr}\end{array}$ & $\begin{array}{r}29 \\
18 \\
-25\end{array}$ \\
\hline
\end{tabular}

Yamato ${ }^{61}$ tudied the extraction of molybdenum from 2-7 M hydrochloric aid by ether, amy l lcohol, anyl acetate, butyl acetato and tholr blnary mixtures. The 1:1 nixtures of ether with butyl acetate, my l alcohol or butyl alcohol extracted over $90 \%$ of the molybdenum. When the solvents tested separately butyl acetate was the bost extractant: $82.5 \%$ of the molybdenum extracted from $5.4 \mathrm{M}$ hydrochloric acld. When the temperature for the extraction was dropped to $10^{\circ}$, over $99 \%$ of the molybdenum was extracted by butyl acetato from 7.5 hydrochloric acld.

Methyl isobutyl ketone (hexone): Waterbury and Bricker ${ }^{62}$ arvised prom cedure for the determination of .01-1.0\% molybdenum in plutonium and plutonium alloys. An liguot of the dissolved maple containing loor or less of molybdenum is de $6 \mathrm{M}$ in hydrochloric acid and $0.4 \mathrm{M}$ in hydrofluoric acid. The aolution is contacted three times with equilibrated hexone and the rolgbdenum in the combined organic phases is back-atracted with throe portions of water. Molybdenum is then determinod in the aquoue phsse colorimetrically with chloranilic acid after Ireoing the comblnod extracta from hydrofluoric acld 
by hydroxide from dilute alkalino solution.

MrIbuty 1 Phosphte (TBP): TBP is an excellent oxtractant for molybdonum. Nelldow and Diamond ${ }^{17}$ report distribution coefficient $\left[\left(\mathrm{Mo}_{\text {Org. }} /(\mathrm{Mo}) \mathrm{ag}\right]\right.$ Prom 1 M and 2 M hydrochloric acid solutions of 4.0 and 65 respectively with D increaing with increasiag acid concentration. Gerilt 63 reports distribution coefficlents of 8.5 and 21.6 from neutrel mediuand $2 \mathbb{N}$ alfuric acid solutions respectively.

TBP and hexone are used for the solvent recovery of uraniun and plutonium. Under various conditions, both aloo extrect thorium, neptunlum and fisston products such as ruthenium, zirconium, and cerium; TBP can also extract the raxths. 04,65

Other Solvente: Other classos of solvent which prove useful in the solvent extraction of molybdenin are the mono- and di-a.1kylphosphates, the di- and tri-alkylphosphine oxides, and the inple primery, secondary and tertiary amines. While there are no references to the use of these solvente in the radiochemical analysis of molyhdenum, some of them should be quite helpful. A few examples will give some fdee of their possibilities.

More than $99 \%$ of the molybdeaum(VI) was extracted from uranium leach IIquors by 0.4 M DDPA (mono ester of dodecylphosphoric acid) in kerosene. 66

Extraction coefficients of $>1000$ were observed for molybdenum(VI) when sulfuric acid solutions (pE 2) containing $\sim 3 \mathrm{mgs}$ Mo/mI were contacted with an approximately equal volume of $0.1 \mathrm{M}$ solutions of the amines, e.g., 1-(3-ethyl pentyl)-4-ethyloctylamine, dilaurylamine, methyl dilaurylamine, in an aromatic hydrocarbon diluent. Howerex, these mine extractions have the charderistic that as the concentration of molybdenum in the aqueous phase decreases. 80 does its alstribution coefficient. 67

White ${ }^{68}$ studied the extraction behavior of over forty elements with the trialkylphosphine oxides. Molybdenum(VI) was completely extracted from I M hydrochloric or sulfuric acid solutions by $0.1 \mathrm{M}$ tri-n-octylphosphine 
oxide in cyclohexane and partially extracted from the sme aqueous media by 0.1 M tris-2-ethylhexylphosphine oxide.

Several papers concerning the extraction of other elements with these solvents were presented at the Second United Nations Intornational Conference on the Peaceful Uses of Atomic Energy. Morrison and Freiser 69 provide a sum mary of the extraction of various elements, including molybdenum, by trialkylphosphine oxides and high molecular weight amines.

\section{Chromatographic Behavior of Molybdemun}

\section{Anion Exchange}

\section{Hydrochloric acid}

Molybdenum(VI) is adsorbed very strongly onto strong base anion resins (Dowex-1 and 2, Amberlite IRA-400) at I0w HCI concentrations $\left(K_{d} 1000-2000\right.$ at $\sim 0.1$ M $\mathrm{HCI}$ ). As the HCI concentration increases, $\mathrm{K}_{\mathrm{d}}$ drops to a minimum $(10-20)$ at 1.5 $\mathrm{M} \mathrm{HCI}$, rises to a maximus $(100-250)$ at $5 \mathrm{M} \mathrm{HCI}$ and then very slowly decreases. 70-73 The dip in the $\mathrm{K}_{\mathrm{d}}$ curve indicates that there are possibly two species of molybdenum present at low HCI concentrations.

Thus molybdenum can be separated from elements which are not adsorbed strongly at high HCL concentrations. Kraus and Nelson ${ }^{74}$ have compiled data for the adsorption from hydrochloric acid solutions onto Dowex-1 for essentially all the elements in the periodic table. The alkali metals, alkaline earths, rare earths, yttrium, actinium, thorium, nickel and aluminum are not adsorbed from HCI solutions.

Uranium, neptuniure, plutonium(VI) and (IV), niobiur and tungsten are adsorbed strongly from $>6 \mathrm{M} \mathrm{HCI}$, airconium from $>8 \mathrm{M} \mathrm{HCI}$ and protactinium from $>10 \mathrm{M}$ HCI. Americium is not adsorbed from $\mathrm{HCI}$ solutions.

On the other hand, molybdemum should be separable from elements that are adsorbed strongly from 1-2 M HCl. Huffman, Oswalt and Willians ${ }^{72}$ separated molybdenum fron technetiu on a Dowex-1 column ( $3 \mathrm{~m} 21 \mathrm{~m})$, chloride form. Molybdenum was removed quantitatively by elution with $1 \mathrm{M} \mathrm{HCI}$ and technetium was then removed with $4 \mathrm{HNO}_{3}$. 


\section{Nitrice sulfuric and phosphoric acids}

Distribution coefficients have been determined for the adsorption of molybdenum and other elements onto Dowex-2 from nitric ${ }^{73}$, sulfuric ${ }^{73}$ and phosphoric ${ }^{75}$ acid solutions. Molybdenum is adsorbed very strongly from all three acids at $0.1 \mathrm{~N}$ acid concentration and then the adsorption drops rapidiy with increasing acid concentration.

At $0.1 \mathrm{~N} \mathrm{HNO}_{3}, \mathrm{~K}_{\mathrm{d}}$ is 500 and then drops with increasing acid concentration to 0.4 at $11 \mathrm{~N} \mathrm{HNO}$. Yttrium, Sr, $\mathrm{Ce}$, Am and $\mathrm{Nb}$ are not adsorbed; $\mathrm{Tm}_{\mathrm{H}} \mathrm{U}(\mathrm{VI})$ and $\mathrm{Zr}$ are not adsorbed below $1 \mathrm{~N} \mathrm{HNO}_{3}$ and all three peak around $8 \mathrm{~N} \mathrm{HNO}_{3}$. For protactinium, $\mathrm{K}_{\mathrm{d}}$ at $0.1 \mathrm{~N} \mathrm{HNO}_{3}$ is 3 , stays fairly constant to $1 \mathrm{~N} \mathrm{HNO}_{3}$ and then rises to a peak at $8 \mathrm{~N} \mathrm{HNO}_{3}$. Ruthenium behaves like molybdenum, but its adsorpm tion drops much less rapidly.

In sulfuric acid, the $\mathrm{K}_{\mathrm{d}}$ for molybdenum is 10,000 at $0.1 \mathrm{~N}_{2} \mathrm{SO}_{4}$ and drops to 11 at $12.5 \mathrm{~N} \mathrm{H}_{2} \mathrm{SO}_{4}$. Niobium, U(VI), $\mathrm{Zr}$ and $\mathrm{Pa}$ behave similarly though none have as high a $\mathrm{K}_{\mathrm{d}}$ in dilute $\mathrm{H}_{2} \mathrm{SO}_{4}$ as molybdenum. Strontium, $\mathrm{Y}_{2} \mathrm{Ce}$ and Am did not show any significant adsorption. Thorium and Ru have relatively low $_{\mathrm{d}}$ 's in dilute acid; adsorption drops to a minimum at $1-2 \mathrm{~N} \mathrm{H}_{2} \mathrm{SO}_{4}$ and then rises again. Thorium adsorption shows a peak at $11 \mathrm{~N} \mathrm{H}_{2} \mathrm{SO}_{4}$.

Nolybdemum has a $\mathrm{K}_{\mathrm{d}}$ of $\sim 60,000$ in $0.1 \mathrm{~N} \mathrm{H}_{3} \mathrm{PO}_{4}$; the $\mathrm{K}_{\mathrm{d}}$ decreases rapidly to 4 at $\sim 12.5 \mathrm{M} \mathrm{H}_{3} \mathrm{PO}_{4}$. Zirconium, $\mathrm{Nb}, \mathrm{U}(\mathrm{VI})$ and $\mathrm{Np}$ behave similarly. Cesium and $\mathrm{Te}$ (IV) distribution coefficients are less than $I$ and $\mathrm{Ce}$ and $\mathrm{Sr}$ distribution coefficients are less than 10 from $0.1 \mathrm{~N}$ to $12 \mathrm{~N}_{3} \mathrm{PO}_{4}$.

Buchanan, et al., studied the adsorption of sixty elements onto Dowex-1 from nitric acid media. They found that molybdenum(VI) is not adsorbed from $1 \mathrm{~N}$ to $14 \mathrm{~N} \mathrm{HNO}_{3} \cdot 76$

\section{Hydrochlorichydrofluoric acid}

The adsorption behavior of molybdenum in HCI-HF-anion exchange systems has been studied by several investigators. The presence of Iluoride ion has made possible several separations which were not feasible in hydrochloric acid solutions. 
Hague, Brown and Bright 77 determined conditions for the separation of titanium, tungsten, molybdenum and niobium from each other on Dowex-1 (8-10 per cent cross linkage) with HCImHF solutions.

Kraus, Nelson and Moore ${ }^{71}$ separated molybderux, tungsten ard uraxium from ach other on a Dowex-1 column (10 per cent cross linkage, 200-230 mesh). The three elements were put on the column in $0.5 \mathrm{M} \mathrm{HCl-1} \mathrm{M} \mathrm{HF}$, uranium was eluted with $0.5 \mathrm{MHCl}-1$ M HF, tungsten was removed next with $9 \mathrm{M} \mathrm{HCL-1} \mathrm{MF}$ and molybdenum was eluted last with I M HQ.

Wish ${ }^{78}$ has combined elutions with $\mathrm{HCl}-\mathrm{HF}, \mathrm{H}_{3} \mathrm{PO}_{4}$ and $\mathrm{HNO}_{3}$ to provide a method for the rapid, carrier-free separation of $\mathrm{Np}, \mathrm{Pu}, \mathrm{U}, \mathrm{Zr}, \mathrm{Nb}, \mathrm{Te}$ and $\mathrm{Mo}$ from each other and their quantitative recovery from mixed fission product solutions on Dowex-2 (see Procedure D, Section VI in this report).

Baxnes and Iang 79 (see Procedure B, Section VI in this report) and Stevenson, Hicke and Levg 80 have developed procedures for the radochemical deterwination of molybdenum(VI) from mixed fission product colutions us ing lonexchange techriqued. Their procedures are briefly: adsorption of molybdenum(VI) from $6 \mathrm{M}$ HCI onto an $10 n$ exchange resin, Wahing the roin with rarlous eluants, atripping molybdenum off the rosin with $6 \mathrm{M} \mathrm{NaOH}$ or. $6 \mathrm{M}$ amonitu acetate, scavonging the molybdenum-contalning efrluent with ferzic hydroxide and then precipitation of molybdenum for yield determinations and counting.

\section{Other Media}

The behavior of rhenium and molybdenum on IRA-400, chlorate form, (IRA-400 Is atrong base anion realn) vith potassium oxalate has been incorporeted into a procedure for the separation of cro quantities of molybdenum from rhenium. The elements are loaded onto the resin frow alkaline solution, molybdenum is removed with I M potasalua oxalate and rhenium is stripped off with $1 \mathrm{MC} 1 \mathrm{H}_{4} .70$

Molybdenu target terial wa separated from $\mathrm{Te}^{99}$ on IRA-400, eblorate form, by atripping off the molybdenum with $\mathrm{K}_{2} \mathrm{C}_{2} \mathrm{O}_{4}-\mathrm{K}$. with $\mathrm{TC}^{99}$ with $0.5 \mathrm{M} \mathrm{NH}_{4} \mathrm{SCN}$. 81

Blas fus, Pittak and Negwer 82 report a rather unique procedure for the separetion of amounts of tungaten from molybdenu by taking advantage of 
a small-pored Pormutit-RS resin, chloride form. The tungstoborate lon is formed in the presence of molybdate by addition of $\mathrm{H}_{3} \mathrm{BO}_{3}$ and NaCAC at $\mathrm{pH} 5.8$. The aqueous solution of the crystalline alurry is adjusted to 5 N HCl. This solution is then passed through the column of Permutit-ES resin. Molybdenum is adsorbed, but the tungstoborate lon, due to its large size, cannot penetrate the pores of the resin and thus passes through the column. Molybdenum is eluted with NaOAC.

\section{Cation Exchange}

The question of the existence of a cationic species of molybdenum(VI), such as $\mathrm{MOO}_{2}{ }^{+2}$, has not been settled. Diamond 83 reports that there was little or no adsorption of molybdenum on Dowex-50 (cation resin) from 1-12 M BCl or 1-6 M $\mathrm{HBr}$, $\mathrm{HP}, \mathrm{H}_{2} \mathrm{SO}_{4}$ or $\mathrm{HNO}_{3}$ solutions but that from $1-6 \mathrm{M} \mathrm{HClO}_{4}$ there was slight adsorption on the cation resin.

\section{Paper Chromatography}

The technique of paper chromatography has not been extensively employed for radiochemical separations. However a large number of systems bave been studied for other purposes and a great variety of separations can be made. Reviews of the subject have been prepared by Weil 84 and We11s. 85

An example of molybdenum separation by paper chromatography is that of Mo(III) in dilute $\mathrm{BC} I$ by use of the developer $n$-butanol saturated with 2 N $\mathrm{HNO}_{3}$ and $2 \mathrm{~N} \mathrm{HCl} \mathrm{H}^{86}$ Molybdenum is separated from $\mathrm{U}, \mathrm{V}, \mathrm{Cr}, \mathrm{Mn}, \mathrm{Fe}, \mathrm{Co}, \mathrm{Ni}$ and $\mathrm{Cu}$ by thio wethod.

Molybdenum(V) can be separated from molybdenum(VI) by filter paper chromatography with a mixture of con. $\mathrm{HCl}: \mathrm{H}_{2} \mathrm{O}:$ ether:MeOH in the ratio 4:15:50:30 87 or by ascending paper chromatography with the solvent $\mathrm{H}_{2} 0$-acetic acid - KSCN. 88

Almassy and Straub 89 developed a specific separation for molybdenum from cations by ascending paper chromatography with the solvent EtOH-con. $\mathrm{HCl}-\mathrm{H}_{2} \mathrm{O}$ (4:1:5). Blasius and Czekay ${ }^{90}$ separated molybdenum from tungsten (as their oxalato complexes) by paper chromatography with $\mathrm{EtOH}-\mathrm{CHCl}_{3}-10$ per cent aqueous 
oxalic acid $(7: 2: 1)$ as the mobile phase. Lederer ${ }^{91}$ separated Re ${ }^{186} 0_{4}^{-}$rrom $\mathrm{MOO}_{4}=$ and $\mathrm{Te}^{99} \mathrm{O}_{4}-$ fron $\mathrm{MOO}_{4}$ with a wixture of butyl alcohol with $\mathrm{N} \mathrm{HCL}$. $1.5 \mathrm{~N} \mathrm{HNO}_{3}$ or $1.5 \mathrm{~N}$ aqueous amonia as the eluant.

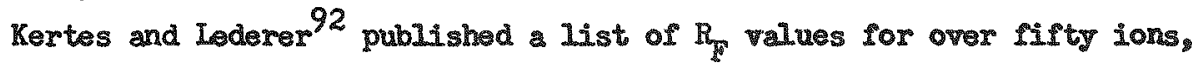
including molybdate, for ascending paper chromatography with five different mixtures of BuOH:HBr:H $\mathrm{H}_{2} \mathrm{O}$ on Whatman No. 1. The $\mathrm{R}_{\mathrm{F}}$ value is defined as the distance travelled by the zone divided by the distance travelled by the Iiquid front.

Thorough coverage of the subject of paper chromatography and its application in the field of inorganic chemistry is provided by Lederer and Lederer 93 and Block, Durrum and Zweig. 94

\section{Electrochemical Behavior of Molybdenum}

The behavior of molybdenum in polarography, controlled potential electrolysis, and constant current mercury cathode electrolysis is of same interest in radiochemical separations. However the use of these techniques has been rather limited with molybdenum and they have had no significant use in radiochemical studies of this element. A recent review of the subject of controlled potential electrolysis is included by Lingane in his comprehensive book on electro analytical chemistry 95 A useful tabulation of elements which can be electrodeposited by the constant current mercury cathode technique is given by IundeII and Hoffman. 96 An excellent review of this subject has also been given by Maxwell and Graham. 97 A more recent detailed examination of the deposition in a mercury cathode of approximately twenty elements is reported by Bock and Hockstein. 98 They found 0.35 per cent of the molybdenum remaining in the aqueous phase after electrolysis of a $0.1 \mathrm{~N} \mathrm{H}_{2} \mathrm{SO}_{4}$ solution for 1.5 hours.

D. Iove 99 describes a procedure for determining fission product $\mathrm{Mo}^{99}$, which, while not directly involving molybdenum, is of interest. $\mathrm{Tc}^{99 \mathrm{~m}}$ the daughter product of $\mathrm{Mo}^{99}$ decay, is amalgamated with $\mathrm{Hg}$ through selective polarographic reduction at a dropping $\mathrm{Hg}$ electrode. The amalgam is counted and Mo ${ }^{99}$ activity determined by making the appropriate corrections. 


\section{DISSOLUTION OF SMMPLES FOR RADIOACTIV MOLYBDENUM DETERMTNATIONS}

One of the probiems the radiochemist must deal with in the dissolution of a sample for a radiochemical determination is assurance that exchange between the added inactive carrier and the radioisotopes of the element to be determined is complete.

If the radioactive isotope can be present in several oxidation states at the same time, one or more of which are difficult to oxidize or reduce, if it tends to form colloids or polymeric species, or if equilibrium rates between different species are slow, etc., exchange may be difficult to obtain.

In the case of molybdenum, treatment of the saple with strong oxidizing agents such as nitric acid, concentrated sulfuric acid, bromine, or strong oxidizing fluxes will generally achieve exchange and oxidize molybdenum to the +6 oxidation state.

However, a word of caution about the use of perchloric acid. Molybdenum apparently exists to a certain extent in a species in perchloric acid that is quite different from the species existing in nitric, sulfuric, hydrochloric acids, etc, and wich behaves differently from these other spocies in sone of the chemical reactions involved in molybdenum radiochemical separations. Thus if perchloric acid has been used in the dissolution of the sample it has been found advantageous to remove it by fuming with concentrated sulfuric acid before performing any subsequent chenistry. 100

For dissolution procedures for a wide variety of samples for the deter mination of molybdenum, consult Snell and Snel1's "Colorimetric Methods of Analysis"47 and Sandelz's "Colorimetric Determination of Traces of Metals" 48

\section{COUNTING TECHIQUES FOR RADIOACTIVE MOLYBDENUM}

Molybdenum 99 is generally the only radioactive isotope of molybdemum isolated from mixed fission product solutions; the other molybdenum fission product isotopes are very short lived, of the order of minutes or less. 
Molybdenum 99 has a 66.0-hour half-1ife and decays via a 1.18-Mev $\beta^{-}$ (83 per cent) to technetium $99 \mathrm{~m}$. Technetium $99 \mathrm{~m}$ has a 6.0 -hour half-life and decays via $r$ emission to technetium 99 which has a long half-life, $-2 \times 10^{5}$ years.

The activity of molybdenum 99 may be measured by either a beta- or gammacounter. In the latter case it is necessary to allow the technetium $99 \mathrm{~m}$ daughter activity to reach equilibrium with the parent activity before counting. How ever, if the activity is measured in a beta-counter, an aluminum absorber of approximately $13 \mathrm{mg} / \mathrm{cm}^{2}$ may be used to remove the conversion electrons from technetium $99 \mathrm{~m}$ and the sample may be counted immediately instead of waiting for equilibrium to be reached.

\section{COLTEGTION OF DETAIIED RADIOCHEMICAL PROCEDURES FOR MOLYBDENUM} MOLYBDENTM

FROCRDURE A

\section{INIRODUCTION}

This procedure for the radiochemical determination of Mo in fission product mixtures is based on precipitation reactions and is derived from the procedures of Ballou ${ }^{101}$ and Scadden. 102 The main steps are precipitations of Mo with a-benzoinoxime, precipitate dissolution and removal of coprecipitated impurities on ferric hydroxide, followed by precipitation of $\mathrm{PbH}_{4}$ for chemical yield determination and counting. Precision of individual determinations is about 1 per cent (standard deviation), and purities are greater than 99 per cent. Chemical yields are about 75 per cent and four determinations can be made in about 4 hours.

If tungsten is present, it will not be separated from Mo by this procedure. Interference by $\mathrm{V}$ or $\mathrm{Cr}$, if present, can be eliminated by reducing them with $\mathrm{H}_{2} \mathrm{SO}_{3}$ prior to precipitation of Mo with a-benzoinoxime 103

\section{PROCEDURE}

1. Ten mg. of molybdenum(VI) are added to the sample in a $40-\mathrm{mI}$. 
PROCEDURE A ( Cont $\left.^{\prime} \mathrm{d}\right)$

centrifuge tube, and the volume is adjusted to $30 \mathrm{ml}$ and the acidity to approximately $1 \mathrm{~N}$ (Note 1 ). Five $\mathrm{ml}$ of 2 per cent $\alpha$-benzoinoxime in ethanol are added, and the mixture stired, then centrifuged at high speed. The precipitate is washed with $30 \mathrm{ml}$ of water.

2. The precipitate is dissolved in $3 \mathrm{ml}$ fuming $\mathrm{HNO}_{3}$; the solution is diluted to $25 \mathrm{ml}$. with water, partially neutralized with 1-2 ml. of conce ammonium hydroxide, and cooled in an ice bath.

3. The molybdemm is reprecipitated by adding $5 \mathrm{ml}$ of the oxime reagent. The mixture is stirred and centrifuged. The precipitate is washed with $30 \mathrm{ml}$ of water.

4. Steps 2 and 3 are repeated.

5. The precipitate of 5 tep 4 is dissolved in $3 \mathrm{ml}$. of fuming nitric acid. Three ml. perchloric acid are added. The solution is boiled to perchloxic acid fumes (caution) and then fumed almost to dryness (Note 2). Then the mixture is cooled.

6. Ten $\mathrm{ml}$. of water and $1 \mathrm{mg}$. of ferric ion are added; ammonium hydroxide is added until the molybdic oxide dissolves and ferric hydroxide has precipitated. The mixture is filtered through any fast filter paper such as Whatman 4 or 41.

7. The filtrate is neutralized with $6 \mathrm{~N} \mathrm{HNO}_{3}$ (litmus paper) and $1.5 \mathrm{ml}$. more of $6 \mathrm{~N} \mathrm{HNO}_{3}$ is added. One ml. of $\mathrm{Pb}\left(\mathrm{NO}_{3}\right)_{2}$ solution (100 $\mathrm{mg}, \mathrm{Pb}^{+2} / \mathrm{ml}$ ) is added and the solution heated to boiling. If a precipitate starts to form one drop conc. $\mathrm{NH}_{4} \mathrm{OH}$ is added, while if no precipitate appears two drops conce $\mathrm{NH}_{4} \mathrm{OH}$ are added. The solution is then boiled for several seconds only (Note 3 ). The solution is filtered hot through a weighed disc of Whatman 42 filter paper and the precipitate is washed with three $5 \mathrm{mil}$ portions of hot water and one $2-3 \mathrm{ml}$ portion of anhydrous methyl 
PROCEDURE A (Cont'd)

alcohol. The precipitate is dried at $105-110^{\circ} \mathrm{C}$ for 15 min. cooled in air for 20 min. wrighed, and mounted for counting (Note 4).

NOTES

1. If the previous history of the sample is such (e.g., reduced) that exchange between carrier and radioactive atoms may be incomplete, digestion with conc. $\mathrm{HNO}_{3}$ is necessary. In addition, the presence of fluoride interferes with subsequent steps and should be removed by fuming with about $1 \mathrm{ml}$. conc. $\mathrm{H}_{2} \mathrm{SO}_{4}$.

2. Much frothing occurs on boiling down the molybdenum oximate-fuming nitric acid-perchloric acid solution, and care must be exercised to prevent loss of solution from the tube.

3. The $\mathrm{PbMOO}_{4}$ precipitate formed in this way yields a reproducibly uniform sample for beta-ray counting. This is desirable since beta-ray counting characteristics of a sample are sensitive to such factors as precipitate clumping and compacting.

4. If beta-ray counting of $\mathrm{Mo}^{99}$ is to be done, an AI absorber (about $13 \mathrm{mg} / \mathrm{cm}^{2}$ ) can be used to remove the conversion electrons of 6.0 -hr $\mathrm{Tc}^{99 \mathrm{~m}}$ and thus eliminate the necessity of waiting for it to grow into equilibrium.

\section{PREPARATTON AND STANDARDIZATTON OF CARRTER}

Dissolve $18.4 \mathrm{~g} \cdot\left(\mathrm{NH}_{4}\right)_{6} \mathrm{MO}_{7} \mathrm{O}_{24} \cdot 4 \mathrm{H}_{2} \mathrm{O}$ in 1 liter $\mathrm{H}_{2} \mathrm{O}$. Standardize by withdrawing quadruplicate aliquots of $5.00 \mathrm{ml}$. and to each aliquot add $80 \mathrm{ml}$. $\mathrm{H}_{2} \mathrm{O}$ and $2.5 \mathrm{ml}$. glacial $\mathrm{HC}_{2} \mathrm{H}_{3} \mathrm{O}_{2}$. Wam almost to the boiling point, add 5.3 ml. of 4 per cent $\mathrm{Pb}\left(\mathrm{C}_{2} \mathrm{H}_{3} \mathrm{O}_{2}\right)_{2}$ solution dropwise and let stand for several minutes. Filter through a tared fine sintered glass crucible, wash precipitate with three $15 \mathrm{ml}$. portions hot $\mathrm{H}_{2} \mathrm{O}$ and with $5 \mathrm{ml}$. anhydrous $\mathrm{CH}_{3} \mathrm{OH}_{\text {. Dry }}$ at $105-110^{\circ} \mathrm{C}$ for 15 min., 0001 in air 20 min., weigh. Repeat drying process to constant weight. 


\section{MOLYBDENUM}

PROCEDUPR B

\section{INTRODUCIION}

This procedure for the radiochemical deterrnination of No in fission product mixtures is based largely on anion exchange resin separations as dem scribed by Barnes and Lang. 79 Another anion exchange procedure which also isolates Mo very effectively has been given by Stevenson, Hicks, and Lerg 80 and differs in some of the eluants used. The main steps in the following procedure are adsorption of Mo on a column of Dowex-I anion exchange resin

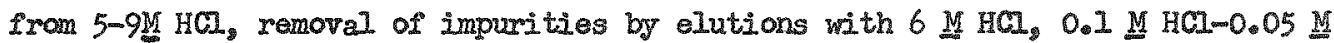
$\mathrm{HF}$, and $3 \mathrm{M} \mathrm{NH}_{4} \mathrm{OH}$ elution of $\mathrm{Mo}$ with $6 \mathrm{M} \mathrm{NH}_{4} \mathrm{C}_{2} \mathrm{H}_{3} \mathrm{O}_{2}$ precipitation of ferric hydroxide for additional decontamination, precipitation of Mo with a-benzoinoxime, and ignition of this precipitate to $\mathrm{MoO}_{3}$ for chemical yield determingtion and counting. Precision of individual determinations is better than 1 per cent (standard deviation), and purities are greater than 99 per cent. Chemical yields are about 75 per cent and eight determinations can be performed in about 4 hours.

If tungsten is present, it will not be removed by the procedure (nor by that of Stevenson, Hicks, and Levy).

\section{PROCEDURE}

1. Add the sample to $3.0 \mathrm{ml}$ of Mo carrier in a $40 \mathrm{mil}$. short-taper conical centrifuge tube. Add $1 \mathrm{ml}$. of $\mathrm{Br}_{2}-\mathrm{H}_{2} \mathrm{O}$ (Note $\mathrm{I}$ ) and bring to a boil over a burner. (If the volume is greater than $10 \mathrm{ml}$. the solution should be evaporated to 5 to $10 \mathrm{ml}$. in a $125-\mathrm{ml}$. Erlenmeyer flask.) Add sufficient conc. HCI to make the solution 5 to 9 In this acid (Note 2).

2. Heat the solution to boiling, transfer to the Dowex-I anion resin column (Note 3 and 4), and permit to run through under gravity. Add 1 to $2 \mathrm{ml}$. of $6 \mathrm{M} \mathrm{HCl}$ to the column, and when the level of acid reaches the top of the resin, add $10 \mathrm{ml}$. of 
hot HF-HCI solution (Note 5). When the level of the HF-HCI solution reaches the top of the resin, add $5 \mathrm{ml}$. of $3 \mathrm{M} \mathrm{NH}_{4} \mathrm{OH}$.

3. As soon as the level of the $\mathrm{NH}_{4}$ Off reaches the top of the resin, all effluents collected to this point are placed in the approm priate waste bottle. Add $10 \mathrm{ml}$ of hot $6 \mathrm{M} \mathrm{NH} 4 \mathrm{C}_{2} \mathrm{H}_{3} \mathrm{O}_{2}$ to the resin and permit to pass through, catching the Mo eluate in a clean 40-ml. centrifuge tube (Note 6).

4. To the eluate add $2 \mathrm{ml}$. of conc. $\mathrm{NH}_{4} \mathrm{OH}$, stir., and then add 10 drops of Fe carrier. Boil for 1 min. with stirring. Centrifuge.

5. Add the supernate to an ice-cold mixture of $6 \mathrm{ml}$. of conc. $\mathrm{HNO}_{3}$, and $1 \mathrm{ml}$ of $\mathrm{Br}_{2}-\mathrm{H}_{2} \mathrm{O}$, and $\mathrm{coOI}$ in an $\mathrm{ico}$ bath for about $5 \mathrm{~min}$. Add $10 \mathrm{ml}$. of a-benzoinoxime solution and stir vigorously. Filter onto No. $4 \mathrm{l}$ H Whatman filter paper, completing the transfer with I $\mathrm{M} \mathrm{HNO}_{3}$

6. Place the filter paper and contents in a porcelain cucible (Coors 0 ) and ignite to $\mathrm{MoO}_{3}$ at $550^{\circ}$ for about $3 / 4 \mathrm{hr}$. (Note 7 ).

7. After ignition allow the cruaible to cool and grind the $\mathrm{MoO}_{3}$ to a fine consistency with the end of a stirring rod. Add 2 drops of ethanol and slurry; then add an additional $5 \mathrm{ml}$. of ethanol, stix, and filter onto a previously washed, dried and weighed No. 42 Whatman filter circle, using a ground-of Hirsch funnel and stainless steel filter chimney. Wash with ethanol and dry at $110^{\circ}$ for about 10 min. Cool, weigh, and mount (Note 8).

\section{NOTES}

I. If the sample contains large amounts of $\mathrm{U}$ or $\mathrm{PO}_{4}^{\mathrm{m}}$, at this point precipitate the Mo with $10 \mathrm{ml}$ of a-benzoinoxime solution. Stir well, centrifuge, and filter onto No. 41 Whatman filter paper. 
Wash the precipitate well with $1 \mathrm{M}_{\mathrm{HNO}_{3}}{ }^{\circ}$ (The filtrate and all washes are placed in the appropriate waste bottle.) Ignite the precipitate for about $15 \mathrm{~min}$. at $550^{\circ}$. Dissolve the $\mathrm{MOO}_{3}$ with 3 drops of conc. $\mathrm{H}_{2} \mathrm{SO}_{4}$ by heating to boiling. Dilute to $5 \mathrm{ml}$. with $6 \mathrm{M} \mathrm{HCI}$, add I ml of $\mathrm{Br}_{2}-\mathrm{H}_{2} \mathrm{O}$, boil, and proceed to Step 2.

2. If it appears that exchange between carrier and radiomolybdenum might be incomplete, perhaps because of the presence of some organic compound, add 0.5 to $1.0 \mathrm{ml}$. of conc. $\mathrm{H}_{2} \mathrm{SO}_{4}$ to sample and Mo carrier and evaporate the solution to dense white fumes. Cool and add 4 to $5 \mathrm{ml}$. of $6 \mathrm{M} \mathrm{HCl}$ and $1 \mathrm{ml}$. of $\mathrm{Br}_{2}-\mathrm{H}_{2} \mathrm{O}$. Then proceed to step 3. (Fuming with conc. $\mathrm{H}_{2} \mathrm{SO}_{4}$ should also be carried out if the sample contains appreciable $\mathrm{NO}_{3}^{-}$ion.)

3. The anion resin, Dowex-1, is prepared for use in the following manner. Place a large quantity of the dry resin in a large tube ( 3 to $4^{\text {" }}$ diameter and 1 to $1-1 / 2^{\text {l }}$ long) with a medium or coarse fritted disk at the bottom. Slurry with methanol or ethanol while the bottom of the tube is stoppered and then suck the resin dry. Slurry the resin with conc. HCI containing about $1 \mathrm{ml}$. of $0.5 \mathrm{M}$ $\mathrm{NaBrO}_{3}$ per $100 \mathrm{ml}$. of $\mathrm{HCl}$ and let the slurry stand for at least 30 min. (Anion resins, as obtained commercially, have reducing properties. The $\mathrm{NaBrO}_{3}$ presumably oxidizes any reducing species present in the resin.) Allow the resin to drain, and then repeat the treatment. Wash the resin with a large volume of distilled $\mathrm{H}_{2} \mathrm{O}$. The tube should be filled with $\mathrm{H}_{2} \mathrm{O}$, slurried, and sucked dry at least fire tines. Slurry the resin with a $1: 1$ mixture of $\mathrm{H}_{2} \mathrm{O}$ and conc. $\mathrm{NH}_{4} \mathrm{OH}$ and let stand for a while. Suck the resin dry and rinse with four to five fillings of distilled $\mathrm{H}_{2} \mathrm{O}_{0}$ Then slurry the resin with $6 \mathrm{M}$ $\mathrm{HCI}$, allow to stand, and suck dry. Slurry again with the acid and transfer the slurry to a storage bottle. 
PROCEDURE B (Cont'd)

4. To prepare the anion column for use: (a) place a small plug of glass wool in the tip of the column; (b) add 4 to 5 cn. height of resin; (c) allow the acid to drain off.

5. The HF-HCI wash removes moderate quantities of $U$ and Pu.

6. If the sample contains macro quantities of $\mathrm{Pu}$, an additional column step should be performed. Add $3 \mathrm{ml}$. of conc. $\mathrm{HNO}_{3}$ to the Mo eluate and precipitate, ignite, and dissolve the Mo as in Note 1. Repeat Step 2, with the exception of the addition of $3 \mathrm{M} \mathrm{NH}_{4} \mathrm{OH}$. Elute Mo with $\mathrm{MH}_{4} \mathrm{C}_{2} \mathrm{H}_{3} \mathrm{O}_{2}$ as in Step 3 and proceed to step 4.

7. A stream of air flowing through the muffle furnace aids in the conversion of the Mo(VI)-benzoinoxime complex to $\mathrm{MoO}_{3}$.

8. The samples can be mounted on AI plates with two-sided Scotch tape and covered with Mylar film. Four drops of Zapon solution (1 per cent Zapon in ethanol) are used to keep the $\mathrm{MOO}_{3}$ under the Mylar film.

\section{PREPARATION AND STANDARDIZATION OF CARRIER}

Dissolve $18.4 \mathrm{~g}$ of $\left(\mathrm{MH}_{4}\right) \mathrm{MO}_{7} \mathrm{O}_{2}, 4 \mathrm{H}_{2} \mathrm{O}$ in $\mathrm{H}_{2} \mathrm{O}$, add I ml. of $0.5 \mathrm{M} \mathrm{NaBrO} 3^{2}$ and dilute to 1 liter with $6 \mathrm{M} \mathrm{HCl}$. Pipet $5.0 \mathrm{ml}$. of the solution into a $50-\mathrm{ml}$. beaker and dilute to about $20 \mathrm{ml}$. Add I ml. of $\mathrm{Br}_{2}-\mathrm{H}_{2} \mathrm{O}, 3 \mathrm{ml}$. of conc. $\mathrm{HNO}_{3}$, and cool in an ice bath for 10 to $15 \mathrm{~min}$. Add $15 \mathrm{mil}$ of a-benzoinoxime solution, stir vigorously, and let stand for $5 \mathrm{~min}$. Filter onto No. 42 Whatman filter paper, rinse the beaker with $1 \mathrm{MNO}_{3}$, and transfer the rinsings to the filter paper. Transfer precipitate and paper to a weighed porcelain crucible (Coors I) and ignite to the oxide at $550^{\circ}$ for $1 \mathrm{hr}$. Cool and weigh the $\mathrm{MoO}_{3}$. 


\section{MOLYBDENUM}

PROCEDURE C

\section{INTRODUCTION}

This procedure for the radiochemical determination of Mo in fission product mixtures is based primarily on ether extractions and is derived from the procedure of Wiles and coryell. 59 The main steps in the procedure are diethyl ether extraction of Mo from about $6 \mathrm{~N} \mathrm{HCl,} \mathrm{remoral} \mathrm{of} \mathrm{co-extracted}$ impurities by ferric hydroxide precipitation, and precipitations of Mo with 8-hydroxyquinoline for chemical yield determination and counting. Precision of individual determinations is about 1 per cent (standard deviation) and purities are greater than 99 per cent. Chemical yields are about 60 per cent and 8 determinations can be made in about 8 hours.

\section{PROCEDURE}

1. To the sample in a $250-\mathrm{ml}$. separatory funnel add $1.0 \mathrm{ml}$. of Mo carrier solution, I $\mathrm{ml}$. Te carrier solution $(10 \mathrm{mg} / \mathrm{ml})$, $2 \mathrm{mg} \cdot \mathrm{Fe}^{+3}$, a few drops $2.0 \mathrm{M} \mathrm{NaBrO}_{3}$ (Note 1), and adjust the total volume to $15-30 \mathrm{ml}$. and the acidity to $6 \mathrm{~N}$ in $\mathrm{HCl}$.

2. Extract the solution with $100 \mathrm{ml}$. diethyl ether which has been equilibrated with $6 \mathbb{N ~ H C l , ~ a n d ~ d i s c a r d ~ t h e ~ a q u e o u s ~ l a y e r ~ ( N o t e ~ 2 ) . ~}$

3. Wash the ether phase twice with $2 \mathrm{ml} .6 \mathrm{~N} \mathrm{HCI}$ and discard the washings. Back extract the Mo with two 10-ml. portions of $\mathrm{H}_{2} \mathrm{O}$. Discard the ether layer.

4. Add $\mathrm{NH}_{4} \mathrm{OH}$ to precipitate $\mathrm{Fe}(\mathrm{OH})_{3}$ (Note 3). Centrifuge and discard the precipitate; add I $\mathrm{mg} . \mathrm{Fe}^{+3}$ to the solution, stir, centrifuge and discard the precipitate.

5. Add $10 \mathrm{mg}$. Re holdback carrier and I drop methyl orange to the supernatant solution. Make the solution just acid with HCI. Add $5 \mathrm{ml}$. of 5 per cent $\mathrm{NaC}_{2} \mathrm{H}_{3} \mathrm{O}_{2}$, heat nearly to boiling and precipitate the Mo by adding $1 \mathrm{ml}$. of 5 per cent 8-hydroxyquinoline in I N HCI (Note 4). Centrifuge, wash the precipitate 
PROCEDURE C (Cont'd)

with $15 \mathrm{ml} . \mathrm{H}_{2} \mathrm{O}$, transfer to a weighed filter disc, wash with 5 $\mathrm{ml}$. ethyl alcohol and with $5 \mathrm{ml}$. diethyl ether, dry at $120^{\circ} \mathrm{C}$ for 15 min., cool in air for 20 min., weigh and mount for counting.

NOTES

1. Addition of $\mathrm{NaBrO}_{3}$ is to ensure the presence of Mo in the extractable hexavalent state. However, if the previous history of the sample is such that exchange between carrier and radioactive atons may be incomplete by this procedure, digestion with conc. $\mathrm{HNO}_{3}$ followed by destruction of the $\mathrm{HNO}_{3}$ with conc. $\mathrm{HCI}$ is necessary.

2. Fission product elements in addition to Wo which are extracted to varying degrees under these conditions are $\mathrm{Ga}, \mathrm{Tc}, \mathrm{As}, \mathrm{Ge}, \mathrm{Te}, \mathrm{Sn}$, $\mathrm{Sb}, \mathrm{I}, \mathrm{Br}$.

3. The $\mathrm{Fe}(\mathrm{OH})_{3}$ precipitation serves to remove most of the contaminating elements extracted by the ether.

4. The precipitation of molybdenum 8-hydroxyquinolate provides additional decontamination from some of the elements extracted with Mo by diethyl ether, in addition to furnishing a suitable gravimetric and counting precipitate for Mo.

\section{PREPARAT TON AND STANDARDIZATION OF CARPIER}

Dissolve $18.4 \mathrm{~g}\left(\mathrm{NH}_{4}\right)_{6} \mathrm{MO}_{7} \mathrm{O}_{24} 4_{4} \mathrm{H}_{2} \mathrm{O}$ in 1 liter $\mathrm{H}_{2} \mathrm{O}$. Standardize the solution by withdrawing quadruplicate aliquots of $2.00 \mathrm{ml}$. and to each aliquot ad $20 \mathrm{ml} . \mathrm{H}_{2} \mathrm{O}$. Make the solutions just acid to methyl orange, add $5 \mathrm{ml} .5 \mathrm{per}$ cent $\mathrm{NaC}_{2} \mathrm{H}_{3} \mathrm{O}_{2}$, heat nearly to boiling and add $2 \mathrm{ml} .5$ per cent 8-hydroxyquinoline in $1 \mathbb{N}$ HCI. Let stand several minutes and filter through a tared fine sintered glass crucible, wash precipitate with $15 \mathrm{ml} . \mathrm{H}_{2} \mathrm{O}, 5 \mathrm{ml}$ e ethyl alcohol, and $5 \mathrm{ml}$. diethyl ether. Dry precipitate at $120^{\circ} \mathrm{C}$ for 15 min. g cool in air 20 min., weigh. Repeat drying process to constant weight. 
MOLYBDENUM

PROCEDURE D

\section{INTRODUCPION}

This procedure for the radiochemical deternination of Mo in fission product mixtures is based on ion exchange techniques which give quantitative recoveries of separated elements. ${ }^{78}$ In addition, several other elements ( $\mathrm{Zr}, \mathrm{Nb}, \mathrm{Np}, \mathrm{U}, \mathrm{Te}, \mathrm{Pu}$ ) are sequentially removed with quantitative recoveries. Direct gamna-ray counting of isolated solutions can be done in a well-type NaI(MI) scintillation counter. Principal steps in the procedure are separation of $\mathrm{Ru}$ by volatilization with $\mathrm{HClO}_{4}$, adsorption of Mo (and other indicated elements) on an anien exchange resin column from conc. $\mathrm{HCl}$, elution of $\mathrm{Zr}$ with $12 \mathrm{~N} \mathrm{HCI-0.06} \mathrm{N} \mathrm{HF,} \mathrm{elution} \mathrm{of} \mathrm{Np}, \mathrm{Nb}$ and Pu with $6.0 \mathrm{~N} \mathrm{HCI-0.06} \mathrm{N} \mathrm{HF}$ (Note 4), elution of $U$ and Te with $0.1 \mathrm{~N} \mathrm{HCl-0.06} \mathrm{N} \mathrm{HF} \mathrm{(Note} \mathrm{6),} \mathrm{and} \mathrm{elution}$ of Mo and $\mathrm{Tc}$ with $12 \mathrm{NHNO}_{3}$. Precision of individual determinations is about 2 per cent (standard deviation), and purities are greater than 99 per cent. Chemical yields are 100 per cent, and about 12 determinations can be made in a day.

\section{PROCGDURE}

1. To a $1-5 \mathrm{ml}$. sample in a centrifuge tube (Note 1 ) add $1 \mathrm{ml}$. conc. $\mathrm{HClO}_{4}, 1 \mathrm{ml}$. conc. $\mathrm{HNO}_{3}$, and 2 drops conc. $\mathrm{H}_{2} \mathrm{SO}_{4}$, heat to fumes of $\mathrm{H}_{2} \mathrm{SO}_{4}$ (Note 2), Iet cool and carefully add about $2 \mathrm{mI}$. conc. $\mathrm{HCl}$.

2. Quantitatively transfer the solution to $a 0.2 \mathrm{~cm}^{2}$ by $6 \mathrm{~cm}$. high column of Dowex-2 anjon exchange resin in the chloride form using washes of conc. HCl as required. Remove $Z r$ quantitatively from the column by elution with $12 \mathrm{ml} .12 \mathrm{~N}$ HCI-0.06 N HF containing 2-3 drops of $\mathrm{Br}_{2}$ water (Note 3). A flow rate of 1 drop per 10 seconds is used here and in subsequent elution steps. Elute $\mathrm{Np}, \mathrm{Nb}$ and $\mathrm{Pu}$ quantitatively with $12 \mathrm{ml} \cdot 6.0$ 
PROCEDURE D (Cont'd)

N HCl-0.06 N HF containing 2-3 drops of conc. $\mathrm{HNO}_{3}$ (Notes 3 and 4).

3. Dry the column by allowing air to pass through it and then washing it with 3-4 $\mathrm{ml}$. ethyl alcohol (Note 5). After the alcohol has drained through, remove $U$ and Te quantitatively by elution with $12 \mathrm{ml}, 0.1 \mathrm{~N} \mathrm{HCl}-0.06 \mathrm{~N} \mathrm{HF}$ (Note 6).

4. Elute Mo and Tc quantitatively from the column in $12 \mathrm{ml} .12 \mathrm{~N}$ $\mathrm{HNO}_{3} \cdot$ Count the eluate directly in a well-type $\mathrm{NaI}$ (TI) scintillation counter (Note 7).

NOTES

1. Since recoveries are quantitative by this procedure, addition of carriers is not necessary.

2. Distillation with $\mathrm{HClO}_{4}$ serves to remove $\mathrm{Ru}$ which is otherwise likely to contaminate $\mathrm{Zr}$ and other fractions in an irrepro ducible way. If recovery of thu is desired the distillation can be performed in a distillation apparatus made from a 30-40 ml. test tube with an air inlet tube reaching nearly to the bottom of the test tube. A side arm delivery tube is exhausted into a $\mathrm{Ru}$ collecting solution of $2-3 \mathrm{~N} \mathrm{NaOH}$. The distillation is performed with an air stream passing through the system。

3. The eluant contains an oxidizing agent to keep Mo and $U$ in their highest oxidation states.

4. If either $\mathrm{Np}$ or $\mathrm{Nb}-\mathrm{Pu}$ fractions free of the other are desired, a two-step elution can berformed at this point. Following removal of $\mathrm{Zr}$, the $\mathrm{Np}$ can be quantitatively eluted with $12 \mathrm{ml}$. $6.5 \mathrm{~N} \mathrm{HCI}-0.004 \mathrm{~N} \mathrm{HF}$ 。 Then the $\mathrm{Nb}$ and $\mathrm{Pu}$ can be quantitatively eluted together with $12 \mathrm{ml}$. $6.0 \mathrm{~N} \mathrm{HCI-0.06} \mathrm{N} \mathrm{HF。}$ 


\section{PROCEDURE D (Cont'd)}

5. The resin must be dried before elution of $U$ and $T e$ or some Mo will be lost in that fraction due to the minimum in the $\mathrm{MO}_{\mathrm{d}}$ curve at about $2 \mathrm{~N} \mathrm{HCl}$.

6. If isolation of separate $T e$ and $U$ fractions is desired, a twostep elution can be performed at this point. 104 Following removal of the $\mathrm{Nb}$ fraction the column is washed with $3-5 \mathrm{ml}$. of abselute alcohol made $I N$ in phosphoric acid. Te is quantitatively eluted with $25 \mathrm{ml} .1 \mathrm{~N} \mathrm{H}_{3} \mathrm{PO}_{4}{ }^{\circ}$ The resin is converted back to the chloride form with $3-5 \mathrm{ml}$. of absolute alcohol saturated with HCI gas. Then $U$ is quantitatively eluted with $12 \mathrm{mI}$. $0.1 \mathrm{~N} \mathrm{HCI}-0.06 \mathrm{~N} \mathrm{HF}$.

7. Gamna-ray counting is done in a $3^{n}$ diameter by $3^{n}$ high $\mathbb{N a I ( T I )}$ crystal with a well about 1-1/8r diameter by 2-1/48 deep. With such a crystal, counting efficiencies are insensitive to volume differences of $2-3 \mathrm{ml}$. 


\section{REFERENCES}

1. "Oxidation Potentials", W. M. Latimer, 2nd Edition, p. 252, PrenticeHall, Ino., New York (1952)

2. T. Dupuis and C. DuvaI, Anal. Chim. Acta 4, 173-9 (1950)

3. S. C. Liang and K. N. Chang, Science Record 2, 366-72 (1949)

4. R. Pribil and M. Malat, Collection Czech. Chem. Comm. 15, 120 (1950)

5. M. Malinek, Chem. Listy 48, 38 (1954)

6. H. Knowles, Bur. Stds. J. Research 9, 1 (1932)

7. J. B. Bial, "Radiochemical Studies: The Fission Products", C. D. Caryell and N. Sugarman, eds., National Nuclear Energy Series, Div. IV, Vol. 9, Book 3, 1536, McGraw-Hill Book Co., New York (1951)

8. G. Wilkinson and W. Grummitt, Nucleonics 9, No. 3, 52 (1951)

9. "Inorganic Thermogravimetric Analysis", CI. Duval, Chapter 39, Elsevier Publishing Co., New York (1953)

10. E. Picket and B. Hankins, Anal. Chem. 30, 47 (1958)

11. H. Gest and L. Glendenin, National Nuclear Energy Series, Div. IV, Vol. 9, Book I, 170 (1951)

12. B. Park, Ind. Eng. Chem., Anal. Ed. 6, 189 (1934)

13. F. Pohl, Z. Anal. Chem. 142, 19 (1954)

14. K. Scharrer and W. Eberhardt, Z. Pflanzenernahr. Dung. Bodenk. 73, 115 (1956); Chem. Abstrs. 51, 2461 (1957)

15. H. Weiss, private communication, data to be published.

16. I. Lindqvist, Acta Chem. Scandia 5, 568 (1951) (in English)

17. I. Nelidow and R. Diamond, J. Phys. Chem. 59, 710 (1955)

18. R. Diamond, ibid. 61, 69,75 and 1522 (1957)

19. D. Perrin, J. Am. Chem. Soc. 80, 3540 (1958)

20. J. McKaveney and H. Freiser, Anal. Chem. 29, 290-2 (1957)

21. J. Hamence, Analyst $65,152-4$ (1940)

22. Co. M. Miler, J. Ohem. Soc. 151, 792 (1941)

23. T. Gilbert, Jr., Thesis, (Univ• of Minn., Minneapolis) • Univ. Microfilms (Ann Arbor, Mich.) Publ. No. 22489, 156 pp.; Dissert. Abstrs. 17, 1894 (1957)

24. J. Wells and R. Pemberton, Analyst 72, 185 (1947)

25. B. Bagshawe and R. Truman, Analyst $\overline{72}, 189$ (1947)

26. C. Bickford, Wo Jones and J. Keene, J. Am. Pharm. Assoc., Sci. Ed., 37, 255 (1948)

27. $\bar{H}_{0}$ Short, Analyst 76, 710 (1951)

28. C. Piper and R. Beckworth, J. Soc. Chem. Ind. 67, 374-9 (1948)

29. L. Clark and J. Axley, Anal. Chem. 27, 2000-2003 (1955)

30. P. Jeffrey, Analyst 81,104 (1956)

31. A. North, Analyst 81, 660-68 (1956)

32. A. Ashbrook, Chemist-Analyst 48, No. 1,5 (1959)

33. S. Allen and Ho Hamilton, Anal. Chim. Acta 7, 483 (1953)

34. R. Pecsok and D. Sawyer, J. Am. Chem. Soc. 78, 5496-500 (1956)

35. A. Majumdar and J. Ray Chowdhury, Anal. Chim. Acta 19, 576-7 (1958) 
36. R. Taylor, Ph.D. Thesis, Princeton Univ., Dissert. Abstrs. Ily, 1522 (1954)

37. N. Furman, W. Mason and J. Pekola, Anal. Chem. 21, 1325 (1949)

38. D. R. Norton, $\mathrm{M}-3082$, Nov. 1945, decl. Jan., 1956; Nuc. Sci. Abstrs. 10, 6183 (1956)

39. R. Meyer and C. Rulfs, Anal. Chem. 27, 1387 (1955)

40. P. Jeffrey, Analyst 81, 104 (1956)

41. G. Goldstein, D. Nanning and O. Menis, Anal. Chem. 30, 539 (1958)

42. G. Almassy and $M$. Vigvari, Magyar Kem. Folyoirat 62, 332 (1956); Chem. Abstrs. 52, 7941 (1958)

43. E. Sudo, J. Chem. Soc. Japan, Pure Chem. Sect. 77, 1451-3 (1956); Chem。 Abstrs. 51, L201 (1957)

44. S. Luang and P. Hsu, Acta Chim. Sinica 22, 171 (1956); Anal. Abstrs. 4, 2591 (1957)

45. E. Malouf and M. Wnite, Anal. Chem. 23, 497-9 (1951)

46. F. Will III and J. Yoe, Anal. Chim. Acta 3, 546-57 (1953)

47. "Colorimetric Vethods of Analysis", Snell and Snell, Vol. II, Chap. 26, 3rd Edition, (1949) and Vol. IIA, Chap. 26, 3rd Edition, D. Van Nostrand Co., Inc., New York (1959)

48. "Colorimetric Determination of Traces of Metals", E. B. Sandell, Chap. 28, 3rd ed., rev॰, Interscience Publishers, Inc., New York (1959)

49. G. Hiskey and V. Meloche, J.Am. Chem. Soc. 62, 1565 (1940)

50. R. Bock, Z. Anal. Chem. 133, 110 (1951)

51. H. Goto and S. Ikeda, J. Chein. Soc. Japan, Pure Chem. Sect. 77 , 82 (1956); Anal. Abstrs. 3, 2715 (1956)

52. A-2912, Manual of Analytical Methods, I. Basset, D. Pflaum, $R$. kutman, C. Rodden, comps., Vol. III, Pt. 2, p. 163, Sept. 22, 1955, Office of Technical Services, Dept. of Commerce, Washington 25, D. C.

53. F. Martinez and R. Bouza, Quim.e ind. Bilboa 3, 168 (1956); Anal. Abstrs. 4, 2615 (1957)

54. E. Swift, J. Am. Chem. Soc. 46, 2378 (1924)

55. R. Bock, H. Kusche and E. Bock, Z. Anal. Chem. 138, 167 (1953)

56. S. Kitahara, Repts. Sci. Research Inst. (Tokyo) 25, 165 (1949); Chem. Abstrs. 45, 3743 (1951)

57. S. Kitahara, ibia., 24, 454 (1948); Chem. Abstrs. 45, 2290 (1951)

58. P. Stout and W. Meagher, Science 108, 471 (1948)

59. D. Wiles and C. Coryell, Phys. Rev. 96, 696 (1954)

60. NP-3561, Progress Report, Nov. 1951, p. 29; Nuclear Science Abstrs. 6,1424 (1952)

61. S. Yamamoto, J. Cnem. Soc. Japan, Pure Chem. Sect. 76, 417 (1955); Anal. Abstrs. 3, 396 (1956), and ibid. 77, 713 (1956); Anal. Abstrs. 4, 502 (1957)

62. G. Waterbury and C. Bricker, Anal. Chem. 29, 129 (1957)

63. I. Gerlit, International conference on the Peaceful Uses of Atomic Energy, Geneva 1955, Vol. 7, p. 145, United Nations, New York (1956)

64. F. Bruce, ibià., p. 100

65. D. Peppard, W. Driscoll, R. Sironen and S. ycCarty, J. Inorg. and Nuclear Chem。 4,326 (1957)

66. Dow-120, Progress Report for July-August 1954, Sept. 1, 1954, p. 17, decl. Sept. 29, 1955, available from the office of Technical Services, Dept. of Commerce, Washington $25, \mathrm{D} . \mathrm{C}$.

67. "Amine Salts as Solvent Extraction Reagents for Uranium and Other Metals", C. Coleman, K. Brom, J. Moore and Ko Allen, Second United Nations Intermational Conference on the Peacef'ul Uses of Atomic Energy, Geneva 1958, Vol.28, P/510, p. 278, United Nations, New York (1959)

68. "Solvent Extraction", J. C. White, paper presented at First Conference on Analytical Chemistry in Nuclear Reactor Technology, 
Gatlinburg, Tenn., Nov. 1957; TID-7555, August 1958, Office of Technical Services, Dept. of Commerce, Washington 25, D. C.

69. "Solvent Extraction in Analytical Chemistry", G. Morrison and $H_{0}$ Freiser, p. 148-152, John Wiley and Sons, Inc., New York (1957)

70. V. Meloche and. A. Preuss, Anal. Chem. 26, 1911-14 (1954)

71. K. Kraus, F. Nelson and G. Moore, J. Am. Chem. Soc. 77, 3972 (1955)

72. E. Huffman, R. Oswalt and L. Williams, J. Inorg. Nuclear Chem. 3. 49 (1956)

73. T. Bunney, N. Ballou, J. Pascual and S. Foti, Anal. Chem. 3I, 324 (1959)

74. K. Kraus and F. Nelson, International Conference on the Peaceful Uses of Atomic Energy, Geneva 1955, Vol. 7, p. 113, United Nations, New York (1956)

75. E. Freiling, J. Pascual and A. Delucchi, Anal. Chem. 31, 330 (1959)

76. R. Buchanan, J. Faris, K. Orlandini and J. Hughes, paper presented at Reactor Fuel Measurements Techniques Symposium, Michigan State Univ., June 1958; TID-7560, Jan. 1959, office of Technical Services, Dept. of Commerce, Washington 25, D. C.

77. J. Hague, E. Brown and H. Bright, J. Research Nat. Bur. Standards 53, 261 (1954)

78. L. Wish, Anal. Chem. 31, 326 (1959)

79. J. Barmes and E. Lang, "Collected Radiochemical Procedures (Radiochemical Group J-1I)", LASI-1721, 2nd Edition, Aug. 18, 1958, Office of Technical Services, U. S. Dept. of Commerce, Washington 25, D. C.

80. P. Stevenson, H. Hicks and H. Levy, "Radiochemical Procedures in Use at the University of California Radiation Laboratory (Livermore)", UCRL-4377, Aug. 10, 1954, Lawrence Radiation Laboratory, University of California, Berkeley, Calif.

81. N. Hall and D. Johns, J. Am. Chem. Soc. 75, 5787 (1953)

82. E. Blasius, H. Pittak and $\mathrm{H}_{0}$ Negwer, Angew. Chem. 68, 671 (1956)

83. R. Diamond, J. Phys. Chem. 61, 75 (1957)

84. H. Weil, Can. Chem. Processing 38, 68 (1954)

85. R. A. Wells, Quart. Rev. Chem. Soc. I, 307 (1953)

86. F. H. Pollard, J.F. W. McOmie, H. M. Stevens, and J. G. Maddock, J. Chem. Soc., 1338 (1953)

87. F. Pollard, J. McOmie and A. Banister, Chemistry and Industry 1955, 1598

88. M. Candela, E. Hewitt and H. Stevens, Anal. Chir. Acta 14,66 (1956)

89. G. Almassy and J. Straub, Magyar Kem. Folyoirat 60, 104 (1954); Chem. Abstrs. 52, 6053 (1958)

90. E. Blasius and A. Czekay, Z. anal. Chem. 156, 81 (1957)

91. M. Lederer, Anal. Chim. Acta 12, 146 (1955)

92. S. Kertes and M. Lederer, Anal. Chim. Acta 15, 543 (1956)

93. "Chromatography", E. Lederer and If. Lederer, 2nd ed., Elsevier Publishing Company, New York (1957)

94. "A Manual of Paper Chromatography and Paper Electrophoresis", R. Block, E. Durrum and G. Zweig, 2nd ed., Academic Press Inc., New York (1958)

95. J. J. Iingane, "Electroanalytical Chemistry", 2nd ed., Interscience Publishers Inc., New York (1958)

96. G. E. F. Lundell and J. I. Hoffman, "Outlines of Methods of Chemical Analysis", John Wiley and Sons, Inc., New York (1938)

97. J. A. Maxwe17 and R. P. Graham, Chem. Revs. 46, 471 (1950)

98. B. Bock and K. G. Hockstein, Z. anal. Chem. 138, 339 (1953)

99. D. Love, U. S. Naval Radiological Defense Laboratory, paper presented at the Third Conference on Analytical Chemistry in Nuclear Reactor Technology, Oct. 1959, Gatlinburg, Tennessee

100. L. Wish, private communication. 
101. N. E. Ballou, National Nuclear Energy Series, Div. IV, Vol. 9, C. D. Coryell and N. Sugarman, eds., Paper 257, McGraw Hill Book Co.s Inc., New York, N. Y. (1951)

102. E. Mo Scadden, Nucleonics 15 , No. 4, 102 (1957)

103. G. E. F. Lundell and J. I. Hoffman, "Outlines of Methods of Chemical Analysis", p. 12I, John Wiley and Sons, Inc., New York, N. Y. (1938)

104. L. Wish, U. S. Naval Radiological Defense Laboratory, Report USNRDL-TR-312, March 27, 1959 


\title{
NUCLEAR SCIENCE SERIES: MONOGRAPHS ON RADIOCHEMISTRY AND RADIOCHEMICAL TECHNIQUES
}

\author{
Available from the National Technical information Service, \\ U. S. Department of Commerce, Springfield, Virginia 22161
}

\section{ELEMENTS}

Aluminum and Gallium, NAS-NS-3032 [1961] $\$ 925$

Americium and Curium, NAS-NS-3006 [1960] $\$ 9.75$

Antımony, NAS-NS-3033 [1961], \$9.50

Arsenic, NAS-NS-3002 (Rev.) [1965], $\$ 9.00$

Astattne, NAS-NS-3012 [1960], \$8.75

Barum, Calcium, and Strontrum, NAS-NS3010 [1960], $\$ 11.00$

Beryllum, NAS-NS-3013 [1960], $\$ 9.50$

Bismuth, NAS-NS-3061 [1977], $\$ 11.75$

Cadmium, NAS-NS-3001 [1960], $\$ 9.50$

Carbon, Nitrogen, and Oxygen, NAS-NS-

$3019[1960], \$ 8.50$

Cesium, NAS-NS-3035 [1961], \$9.75

Chromium, NAS-NS-3007 (Rev.) [1963], $\$ 9.50$

Cobalt, NAS-NS-3041 [1961], $\$ 10.25$

Copper, NAS-NS-3027 [1961], \$9.50

Ftuorıne, Chlorine, Bromine, and lodine, NAS-NS-3005 [1960], $\$ 9.25$

Franclum, NAS-NS-3003 [1960], $\$ 9.00$ Germanium, NAS-NS-3043 [1961], \$9.25 Goid, NAS-NS-3036 [1961], $\$ 9.00$

Indium, NAS-NS-3014 [1960], $\$ 9.50$

lodine, NAS-NS-3062 [1977], \$11.00

Iridum, NAS-NS-3045[1961], $\$ 8.75$

Iron, NAS-NS-3017 [1960], \$11.75

Lead, NAS-NS-3040 [1961], $\$ 12.00$

Magnesium, NAS-NS-3024 [1961], \$8.75

Manganese, NAS-NS-3018 (Rev.) [1971],

$\$ 9.75$

Mercury, NAS-NS-3026 (Rev.) [1970], $\$ 13.00$

Molybdenum, NAS-NS-3009 [1960], $\$ 9.00$

Neptuntum, NAS-NS-3060 [1974], \$13.75

Nickel, NAS-NS-3051 [1961], \$11.25

Niobium and Tantalum, NAS-NS-3039 [1961],

$\$ 9.50$

Osmium, NAS-NS-3046 [1961], $\$ 8.50$

Palladum, NAS-NS-3052 [1961] \$11.00

Phosphorus, NAS-NS-3056 [1962], $\$ 9.00$

Platınum, NAS-NS-3044 [1961], \$8.75

Plutonum, NAS-NS-3058 [1965], \$12.75

Polonium, NAS-NS-3037 [1961], $\$ 9.75$

Potassium, NAS-NS-3048 [1961], \$9.25

Protactinum, NAS-NS-3016 [1959], \$10.00

Radium, NAS-NS-3057 [1964], \$13.25

Rare Earths-Scandium, Yttrum, and

Actinum, NAS-NS-3020 [1961], \$15.00

Rare Gases, NAS-NS-3025 [1960], \$9.50

Recent Radiochemical Separation Procedures

for As, At, Be, Mg, Ni, Ru, and Se, NAS-NS 3059 [1974], \$10.25

Rhenium, NAS-NS-3028 [1961], $\$ 9.25$

Rhodium, NAS-NS-3008 (Rev.) [1965], $\$ 10.00$

Rubidium, NAS-NS-3053 [1962], \$10.25

Ruthentum, NAS-NS-3029 [1961], \$10.00
Selenum, NAS-NS-3030 (Rev.) [1965], $\$ 9.50$

Silicon, NAS-NS-3049 (Rev.) [1968], $\$ 10.00$

Silver, NAS-NS-3047 [1961], $\$ 9.50$

Sodum, NAS-NS-3055 [1962], $\$ 9.25$

Sulfur, NAS-NS-3054 [1961], $\$ 9.50$

Technetium, NAS-NS-3021 [1960], $\$ 9.50$

Tellurium, NAS-NS-3038 [1960], $\$ 9.25$

Thorlum, NAS-NS-3004 [1960], $\$ 9.75$

TIn, NAS-NS-3023 [1960], $\$ 9.75$

Titanum, NAS-NS-3034 (Rev.) [1971], \$10.25

Transcurium Elements, NAS-NS-3031 [1960]

$$
\$ 9.00
$$

Tungsten, NAS-NS-3042 [1961], \$9.25

Uranium, NAS-NS-3050 [1961], \$17.00

Vanadium, NAS-NS-3022 [1960], $\$ 10.00$

Zınc, NAS-NS-3015 [ 1960$], \$ 9.50$

Zirconium and Hafnum, NAS-NS-3011 [1960] $\$ 9.50$

\section{TECHNIQUES}

Absolute Measurement of Alpha Emission and Spontaneous FIssion, NAS-NS-3112 [1968], \$9.75

Activation Analysis with Charged Particles, NAS-NS-3110 [1966], $\$ 9.25$

Application of Distillation Techniques to Radiochemical Separations, NAS-NS-3108 [1962], \$9.00

Applications of Computers to Nuclear and Radiochemistry, NAS-NS-3107 [1962], \$16.00

Cation-Exchange Techniques in Radiochemistry, NAS-NS-3113 [1971], \$13.00

Chemical Yield Determinations in Radiochemistry, NAS-NS-3111 [1967], \$10.50

Detection and Measurement of Nuclear Radiation, NAS-NS-3105 [1961], \$11.50

Liquid-Liquid Extraction with HighMolecular-Weight Ammes, NAS-NS-3101 [1960], \$1025

Low-Level Radiochemical Separatıons, NAS-NS-3103 [1961], $\$ 9.00$

Neutron Actrvation Technques for the Measurement of Trace Metals in Environmental Samples, NAS-NS-3114 [1974], \$10.25

Paper Chromatographic and Electromigration Technıques in Radiochemistry, NAS-NS3106 [1962], \$9.25

Processing of Counting Data, NAS-NS-3109 [1965], \$12.25

Rapıd Radıochemıcal Separatıons, NAS-NS3104 [1961], \$11.25

Separations by Solvent Extraction with Tri-n-octyiphosphıne Oxide, NAS-NS-3102 [1961], \$9.50

Users' Guides for Radroactivity Standards NAS-NS-3115 [1974], \$10.25 